Spring 3-24-2021

\title{
Mentoring Program for New Graduate Nurses
}

\author{
Kathryn Palermo \\ University of St. Augustine for Health Sciences, k.palermo@usa.edu
}

DOI: https://doi.org/10.46409/sr.NWBA9338

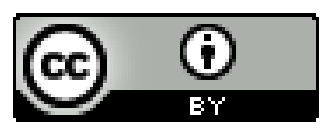

This work is licensed under a Creative Commons Attribution 4.0 License.

Follow this and additional works at: https://soar.usa.edu/scholprojects

Part of the Nursing Administration Commons

\section{Recommended Citation}

Palermo, K. (2021). Mentoring Program for New Graduate Nurses. [Doctoral project, University of St Augustine for Health Sciences]. SOAR @ USA: Student Scholarly Projects Collection. https://doi.org/ $10.46409 /$ sr.NWBA9338

This Scholarly Project is brought to you for free and open access by the Student Research at SOAR @ USA. It has been accepted for inclusion in Student Scholarly Projects by an authorized administrator of SOAR @ USA. For more information, please contact soar@usa.edu, erobinson@usa.edu. 


\title{
Mentoring Program for New Graduate Nurses
}

\author{
Kathryn Palermo, MSN, RN
}

School of Nursing, University of St. Augustine for Health Sciences

This Manuscript Partially Fulfills the Requirements for the

Doctor of Nursing Practice Program and is Approved by:

Sue Bingham, PhD, RN

Jane Braaten, PhD, RN, CPPS, CPHQ

March 24, 2021 


\begin{abstract}
Practice Problem: The high turnover rate among newly licensed nurses has a negative impact on organizational costs, healthcare spending and patient outcomes. The turnover rate among newly licensed nurses, within their first year of practice, at the designated facility was $50 \%$.

PICOT: The PICOT question that guided this project was "In new graduate nurses, how does a formal mentorship program, compared to no formal mentorship, affect the intent to leave within six weeks?"

Evidence: The scientific evidence supported both one-on-one and group mentoring. Retention and/or turnover was shown to be a positive outcome of formal mentor programs.

Intervention: The intervention, aimed at reducing burnout among new graduate nurses, was a formal one-on-one mentoring program that included intentional mentor selection, matchmaking, and mentor training.
\end{abstract}

Outcome: The data demonstrated the intervention of participating in a formal mentorship, as a mentor for six weeks to newly licensed nurses, had a positive impact on the mentors, their job satisfaction, and their intention to continue working on the unit. The data demonstrated the intervention of being mentored, by an experienced nurse on the unit, positively impacted the newly licensed nurses' intention to continue working on the unit and also demonstrated the mentorship program was recommended by all mentors, and mentees, and that the mentors had an impact on the decision of the mentees to stay or leave.

Conclusion: The program altered the working environment of newly licensed nurses and further supported the existing literature regarding formal mentoring programs. The formal mentorship program impacted the problem of high turnover among newly licensed registered nurses positively. 


\section{Mentoring Program for New Graduate Nurses}

New graduate nurses enter the workforce with excitement and a readiness to utilize the skills and knowledge recently gained in nursing school. These feelings can quickly turn to disillusionment and disappointment with the realization of what nursing reality really looks like. With around $25-30 \%$ of nurses leaving the profession within the first year of practice (Bong, 2019; Nursing Solutions Inc., 2020), changes must be made to decrease turnover and to minimize feelings of burnout. This paper is aimed at describing interventions that have been supported by decreasing the instances of burnout, moral distress, and intention to leave their job, among newly licensed registered nurses $(\mathrm{RN})$. The paper will discuss the significance of the problem across the world, regionally, and within the organization described. A thorough description of stakeholders, process and intervention, outcomes, measurement, and data analysis will be offered.

\section{Significance of the Practice Problem}

Burnout among nurses is a significant problem around the world. Studies have shown that nearly $17.5 \%$ of newly licensed nurses leave their first job within 12 months, and $33.5 \%$ leave within 24 months (Silvestre et al., 2017). This turnover is not only costly to employers, but also increases the impact of the current nationwide nursing shortage (Kutney-Lee et al., 2013; Nursing Solutions Inc., 2020), and directly impacts patient outcomes negatively (Choe et al., 2015).

Patients are impacted by nurse burnout in many ways. Nurses who experience burnout are more likely to show ambivalence towards the care they provide (Choe et al., 2015). This ambivalence can manifest as poor prioritization of tasks, lack of awareness of the individual, the practice of medical treatments that are not necessary, and the use of restraints and medications 
when not clinically appropriate (Choe et al., 2015). A lack of empathy and consideration for ethical issues can lead to unnecessary suffering for the patient (Choe et al., 2015).

The impact of burnout does not stop at the patient. While loved-ones are ill, families have a need for open communication and a provider-family relationship. The need to talk and collect information can be challenged when caregivers are experiencing feelings of burnout. Engagement with the patient's family may not happen when nurses are emotionally exhausted. Avoiding direct communication and shared-decision making is a potential problem with nurses who experience feelings of burnout (Buckley et al., 2019).

The average cost (nationwide) to replace a bedside $\mathrm{RN}$ is $\$ 44,000(\$ 33,000-\$ 56,000)$. This translates to an average yearly organizational loss of $\$ 3.6$ million to $\$ 6.1$ million (Nursing Solutions Inc., 2020). The average cost to mentor and train new graduate nurses is an additional $\$ 30,000$ per nurse (Sandler, 2018). While a gap exists within an organization due to an RN shortage, there are costly financial strategies in place. Those strategies include utilizing agency RNs, overtime for current staff, utilization of the company's float pool, and bonus pay to entice workers to work more shifts (Nursing Solutions Inc., 2020). For obvious economic reasons, many healthcare organizations have included turnover rates in their strategic plans.

With an aging population, an increased focus on public reporting, new technologies such as the electronic medical record, and a requirement for lower cost of care and better quality, there is increased pressure from society on the healthcare system. The United States spends around $17.4 \%$ of its gross domestic product on healthcare, which is significantly more than most European countries who spend less than $10 \%$ (Aiken et al., 2012). The need to decrease this spending and increase efficiency has become increasingly difficult with the high rate of turnover related to burnout. Fewer numbers of nurses, combined with changing healthcare, is a 
combination that will likely lead to poor outcomes for patients and the healthcare industry (Aiken et al., 2012). Recent legislative movements in the United States have been aimed at achieving safe nurse staffing and improved working environments. There are currently 20 individual states within the United States that are currently involved in legislation regarding safe nurse staffing (Aiken et al., 2012).

Many countries around the world (Korea, Sweden, Greece, Spain, Poland, Finland, United States, etc.) have been identified as reporting high levels of burnout and dissatisfaction among nurses, with the intention to leave their jobs (Kutney-Lee et al., 2013). In a crosssectional study involving 61,168 bedside nurses and more than 130,000 patients, in 13 countries, it was found that nursing burnout and dissatisfaction is common (as high as $49 \%$ in some countries) around the world (Aiken et al., 2012).

The RN turnover rate in the United States in 2019 was $15.9 \%$. First-year nursing turnover was a staggering 25.3\%. Hospitals in the South Central (AR, AZ, CO, LA, NM, OK, TX \& UT) region of the United States experienced turnover in 2019 at a rate of $16.7 \%$. Hospitals that operated less than 200 beds experienced turnover at $18.0 \%$ in 2019 (Nursing Solutions Inc., 2020). In the 2020 Nursing Solutions Incorporated's (NSI) National Health Care Retention and RN Staffing Report (NSI, 2020), scheduling, immediate manager, workload, staffing ratios and culture were listed as reasons for voluntary termination.

The organization selected for this project was a small 52-bed acute care hospital located an hour south of a metropolitan area in Colorado. The turnover rate for nurses within this facility on the designated unit in 2019 was $41 \%$. The turnover rate for newly licensed RNs within the first three years of practice in 2019 was 50\% (Centura Health, 2020). 


\section{PICOT Question}

The PICOT question for this project was, "In new graduate nurses, how does a formal mentorship program, compared to no formal mentorship, affect the intent to leave within six weeks?"

The population identified for this project was newly licensed registered nurses. The definition of a newly licensed nurse was a registered nurse who had been in the practice setting for less than three years. This specific population was working on the Acute Care Unit at the designated facility. The group was comprised of all adults, male and female, and all baccalaureate prepared registered nurses.

The intervention sought to improve the nurse work environment in a six-week time span from implementation to data collection. Improvements were expected in the areas of relationships, nursing leadership and hospital-wide involvement (Kutney-Lee et al., 2014). The comparison group consisted of the previous new graduate turnover rate (fiscal year 2019) monitored by the human resources department annually. Outcomes were measured by survey results with questions regarding intentions to leave current positions and job dissatisfaction (Kutney-Lee et al., 2014) at six-weeks post implementation.

\section{Evidence-Based Practice (EBP) Model and Change Theory}

Change in nursing is inevitable. The responsibility of a successful project or process change often falls on nursing leaders. Leading change requires support and framework for the change and for the project itself. Because leading change can be so difficult, nurse leaders must be ready to partner and staff, navigate barriers, and generate and utilize resources. 


\section{EBP Model}

The facilitation of practice change, based on existing evidence, was achieved through The Iowa Model (see Appendix A) which guided the EBP process (Iowa Model Collaborative, 2017). The Iowa Model is an algorithm that begins by identifying triggering issues or opportunities within the organization. In this case, an organizational initiative of reducing turnover was selected. Once the problem was identified, the development of the PICOT question and the formation of a team of stakeholders (mentors, new graduate nurses, quality leaders, unit leadership, executive team, and project manager) was completed.

This led to an appraisal and synthesis of literature, through systematic research, where the quality, quantity and consistency of data was compiled. It was determined that sufficient evidence was available to move forward with implementation. A practice change (formal mentor program for new graduate nurses) was designed by utilizing existing programs found in evidence. This practice change included the consideration of resources, approvals needed to implement, collection of baseline data, the development of an implementation (one-on-one mentor training and mentor guide) and evaluation plan (surveys), and finally the preparation of teaching materials.

Following data collection and analysis the project manager utilized the Iowa Model to determine if the change was appropriate to be permanently adopted in practice within the organization. The data proved to be favorable and a sustained practice change was integrated. This change, according to the Iowa Model, was integrated by identifying and engaging key personnel, hardwiring the change into the system, monitoring key indicators and reinforcing as needed (Iowa Model Collaborative, 2017). Finally, results were disseminated within the organization and externally in the form a poster presentation. 


\section{Change Theory}

The Phases of Change Theory was selected because of the focus on the role and responsibility of the intervention, rather than the process of the change (Lippitt et al., 1958). The seven steps in this theory included: 1) diagnostics (problem); 2) assessment of change capacity; 3) resource and motivation assessment; 4) establishing objectives and strategies; 5) role definition of the intervention; 6) change maintenance; and 7) termination of the helping relationship as the culture began to own the change (Lippitt et al., 1958).

All steps within this model placed an emphasis on those who were impacted by the change. This was appropriate for this project because it allowed for involvement from the new graduate nurses in the areas of communication skills, rapport building, problem-solving strategies, and creating ways for feedback (Wagner, 2018).

\section{Evidence Search Strategy and Results}

An evidence search was done using CINAHL Complete database using the terms "new graduate nurses, mentor, and turnover." The date range for the search was 2008-2020 and the search was limited to full-text articles in English. This search yielded 25 articles. Four articles were excluded due to duplication. Inclusion criteria required that the article addressed the PICOT question and offered mentorship that decreased the turnover rate in new graduate nurses. Following an abstract review, five additional articles were excluded because they focused on topics such as graduate nursing programs and other departments unrelated to the practice setting for the project, such as the operating room. Following exclusions, 16 articles were included.

An evidence search was also done using PubMed using the same terms, date range, and language selection. This search yielded 21 full-text articles. Four duplicates to articles found in the CINAHL database were excluded. Thirteen articles were excluded following an abstract 
review due to a focus on topics such as incivility, preceptor models, situational training, recruitment and simulation. There was also a focus on the rural setting in one article which differed significantly from the practice setting. Four articles were included in the evidence and were added to the 16 articles from CINAHL equaling 20 articles. Appendix B displays the evidence search in a PRISMA diagram.

\section{Evidence Evaluation}

Using the final 13 research articles generated by the search strategy the strength of the evidence was determined to be moderate-strong. Using the Johns Hopkins Nursing EBP: Levels of Evidence hierarchy (Dang \& Dearholt, 2012), all articles were ranked by evaluating the quality of the design and validity. Two articles were Level II quasi-experimental studies. The remaining articles included three Level II pilot studies, one Level III retrospective crosssectional study, one Level IV descriptive study, one Level I non-randomized control study, one Level IV opinion paper, and one Level V article based on personal experience/opinion. Three systematic reviews of only randomized control trials were also included at Level V. This was

determined by using the Levels of Evidence Hierarchy by Mosby Elsevier (Ackley et al., 2008). Appendices $\mathrm{C}$ and $\mathrm{D}$ discuss each article individually. Appendix E offers a description of the levels of strength of the recommendation.

\section{Themes from the Evidence}

Due to variability in the literature from program-to-program that described positive outcomes, it was difficult to determine what path would have been the most effective. All mentor programs in the literature were analyzed and compared for common themes. 


\section{Mentorship Programs}

It is important to note that while all articles supported a formal mentorship program, there was some variation among the recommendation of a one-on-one or group mentorship. A one-onone mentorship was suggested to have the potential to decrease turnover anywhere from two to 15\% in one study (Zhang et al., 2019). A one-on-one mentorship was also described as effective in five additional studies (Cottingham et al., 2011; Fox, 2010; Malott, 2012; Schroyer et al., 2020; Williams et al., 2018). Group mentors (one mentor with multiple protégés) were also found to be effective and recommended when incorporated with one-on-one mentorship (Latham et al., 2011; Mallott, 2011, Williams et al., 2018).

\section{Mentor Training}

Four studies specifically discussed the need for formal training for mentors prior to the start of the program. Essential training in one program included certification training, a formal orientation, and periodic training classes. These classes covered topics like conflict resolution, successful mentoring, and skills (Zhang et al., 2018). One study required all mentors to attend classes that addressed learning styles, motivation, and socialization of the new employee (Latham et al., 2011). Two programs also utilized personality testing during the mentor training sessions, like the Myers-Briggs Type Indicator (Fox, 2013; Latham et al., 2011). Required training sessions were also utilized in two other studies where a one-day class was used covering topics like working with different age-groups, how to overcome barriers, critical thinking, and trust building (Fox, 2013; Malott, 2012).

\section{Mentor Recruiting}

The role of the mentor is essential in a formal mentor program. Four studies specifically discussed the need for intentional mentor recruiting and selection. Because the mentor selected 
can directly impact the effectiveness of the program, one article focused a great deal on the selection of the mentor by generating a mentor pool where interested applicants were placed (Zhang et al., 2019). In most studies, mentors were asked to apply for the program instead of being appointed, were nurses who were up-to-date on practice standards, and were considered to be experts on their respective units (Fox, 2013; Latham et al., 2011). In another program, nurse managers used criteria lists in order to select mentors from the pool of experienced nurses (Fox, 2013). In a pilot study, mentors were recruited based on educational levels and were required to hold at least a bachelor's degree in nursing. These mentors were initially recruited through the use of brochures that were hand-delivered if identified by a leader as a potential quality mentor (Cottingham et al., 2011).

\section{Mentor and Protégé Matching}

Nurse managers used criteria lists in order to create pairs in some studies. This process required the pair to have the same educational background, work similar schedules, and may not be expecting to be on leave for more than 12 weeks during the first year (Fox, 2013). In one study, the protégés were allowed to choose their mentor after watching taped clips with viewpoints on nursing (Latham et al., 2011). Another study created a process where the protégé and head nurse selected a mentor together. After the experienced RNs were granted permission to be in the mentor pool, they were then put on the list of available mentors. It was encouraged that the protégé selected a mentor who shared the same values, interests, and hobbies as to enhance mutual attraction (Zhang et al., 2019).

\section{Job Satisfaction}

While most studies were aimed at retention rates, it was discovered that increased job satisfaction was a positive by-product of a formal mentorship program in four studies. Job 
satisfaction was evaluated and described as it related to professional growth goals, informal leadership through the mentor role, increased engagement, supportive relationships, appreciation at work, feelings that mistakes are treated as learning opportunities, shared decision making, and respect (Frost et al., 2013; Halfer et al., 2008; Latham et al., 2011; Schroyer et al., 2020). Results of increased job satisfaction were collected through Likert style questionnaires (Latham et al., 2011), surveys (Schroyer et al., 2020), and interviews (Halfer et al., 2008).

\section{Retention/Turnover}

Eight articles discussed retention and/or turnover as a positive outcome of formal mentor programs. A 325-bed acute care hospital in Indiana saw a 25\% difference in the rate of retained nurses who had a mentor versus those who did not (Schroyer et al., 2020). In a pilot study, a zero percent turnover rate was seen during the first year of the mentor program, a decrease from $31 \%$ to $10.3 \%$ for year two, and a decrease from $31 \%$ to $10.3 \%$ for all other RNs with experience (Fox, 2010). A second study also demonstrated a 100\% rate of retained RNs with the implementation of a formal mentoring program (Cottingham et al., 2011). Over 3,000 new graduate nurses were surveyed across fourteen states in a retrospective cross-sectional study following a formal mentor program, showing that $95.3 \%$ of those newly graduated RNs had no intention to leave their job (Williams et al., 2018). Other studies demonstrated that turnover rates improved anywhere from eight to 21\% (Frost et al., 2013; Halfer et al., 2008; Latham et al., 2011).

\section{Transition to Practice}

Five articles discussed the time period of "transition to practice." It was during this time period where a newly graduated nurse transitioned from the role of a student into the role of a professional nurse. It was during this time period when a newly licensed $\mathrm{RN}$ developed a 
personal practice apart from others and can often feel unprepared for practice and skill mastery

(Berezuik, 2010). It was suggested that mentorship can impact this period of time so significantly, it can directly impact the nurse turnover rate (Zhang et al., 2019). A mentor can help a new graduate nurse by easing the transition from student to practicing nurse (Halfer et al., 2008; Malott, 2012; Williams et al., 2018).

\section{Practice Recommendations}

Following a thorough analysis of the available evidence, it was determined that the recommendation for practice, aimed at reducing burnout among new graduate nurses, was to implement a formal one-on-one mentoring program that included intentional mentor selection, matchmaking, and mentor training. This recommendation was born out of a review of scientific evidence and was based on interventions consistent between multiple studies. For the purpose of this class, results were measured at six weeks.

Using recommendations from two Level II quasi-experimental descriptive studies (Latham et al., 2011; Schroyer et al., 2020) and two Level II pilot studies (Cottingham et al., 2011; Fox, 2010), mentors were selected based off of years-of-experience, desire to mentor, and clinical skill level. Once mentors were selected, they were matched with a protégé based on the recommendation of a Level II quasi-experimental study (Latham et al., 2011), a Level II pilot study (Fox, 2010) and a Level I non-randomized control study (Zhang et al., 2019) by using personality testing, similar schedules, and common interests.

The scientific evidence supported both one-on-one and group mentoring (Latham et al., 2011; Mallott, 2011, Williams et al., 2018). However, the cost of one-on-one mentoring was less expensive and easier to arrange meetings between mentors and protégés (taking into consideration the available resources). The cost-difference and ease of facilitation was 
considered and led to the decision to implement one-on-one mentoring only. One-on-one mentoring was supported by a Level I non-randomized control trial (Zhang et al., 2019), two Level II pilot studies (Cottingham et al., 2011; Fox, 2010), a Level II quasi-experimental study (Schroyer et al., 2020), a Level III retrospective cross-sectional research study (Williams et al., 2018) and a level II pilot study (Malott, 2012).

\section{Project Setting}

The setting was a 28-bed acute care unit serving a mixed population of surgical and medical patients. On average, the unit admitted 10 to 15 patients and discharged 10 to 15 patients in a 24-hour period. The hospital was small and located an hour south of the nearest major city and was a vital resource to many rural communities.

The designated facility was part of a larger organization boasting 17 hospitals, many clinics, stand-alone emergency rooms, and urgent cares throughout two states, thus providing access to many resources that typically would not be available to such a small facility. If the organization chooses to do so, this program could be implemented throughout many hospitals in both states.

The mission of the organization was "to extend the healing ministry of Christ by caring for those who are ill and by nurturing the health of the people in our communities." The vision of the organization was "every community, every neighborhood, every life - whole and healthy."

Organizational need was established and support was confirmed through an evaluation of quality metrics with the director of quality and the Chief Nursing Officer. Both parties agreed that a mentor program could benefit the new graduate nurses entering the workforce. Through use of the Institute of Healthcare Improvement (IHI) self-assessment tool and the checklist to assess organizational readiness (CARI) for EIP implementation, organizational readiness for 
change was addressed. The IHI tool showed rankings in most categories (results, resources, data and competence) at the "significant impact" level. The leadership for improvement category earned a "making progress" ranking (Institute for Healthcare Improvement (IHI), 2010). These scores were based off of previous EBP projects (ex: aromatherapy for nausea), available resources, and overall climate. The CARI tool identified strengths to include organizational capacity/culture, functional considerations, and implementation plan (Barwick, 2010). There was room for improvement in the categories of system and staff capacity, training (smaller facility size limits staff and resource availability), and senior leadership. CARI for EIP implementation is similar to the IHI self-assessment tool because they both allow for an evaluation of the capacity, climate, and support needed for change. Both tools identified an area of weakness in leadership support at both a system and organizational level, which is essential in implementing effective change (Yoo et al., 2019). While the IHI tool showed that previous EBP projects have shown sustained improvement, the CARI tool did not address previous work at all and the impact on readiness. In understanding that organizational culture/climate is essential in reducing barriers to successful EBP implementation (Lundren et al., 2013), it was addressed with the CARI tool specifically (and in general with the IHI tool) and was identified as a strength for the organization. The synthesis of the data suggested that the organization was ready for change and had enough support to do so (Palermo, 2020).

\section{SWOT Analysis}

An analysis of the organization's strengths, weaknesses, opportunities and threats (SWOT) was completed in order to offer a better awareness of the current status and to assist in planning and decision-making (see Appendix F). In light of the high rate of burnout and turnover, it was important to determine what the best path was and where change was possible. 
In this analysis, it was identified that strengths included the membership within a large organization, an established preceptor program, supportive executive team, motivated hospitalwide educator and diverse nursing team. Opportunities included the lack of a mentor program, a large number of new graduate nurses three times per year and much room for improvement in the turnover rate.

The SWOT analysis also included the evaluation of negative aspects within and outside of the organization. Weaknesses or limitations included a limited number of mentors among the nursing staff, a short amount of time to implement the project, small budget, no available time for formal mentor training and the physical limitations related to the pandemic. Threats discovered included the possibility of new graduate acceptance into a residency program at six months, further budget cuts within the organization and decreased healthcare utilization related to the pandemic.

\section{Project Overview}

The vision and mission of this project were to create a culture that supported new graduate nurses professionally, emotionally and mentally. The objectives of the project were to implement a formal mentor program for all new graduate nurses and to see a decrease in the intent to leave in that same population at the end of six weeks. The mission and vision of the organization sought to extend healing to those who are ill and to maintain health in all parts of the community. The organizational mission and vision were in alignment with the project's mission and vision as they all sought to achieve and maintain health.

The short-term objective was to develop and implement a formal mentoring program for all new graduate nurses by October, 2020. This formal mentoring program was built on the 
recommendations based on the literature. The long-term objective was to see $</=50 \%$ intent to leave rate within the new graduate nurse population by six weeks.

Risks of the project included the chance that the mentors and protégés would not connect on a personal level, which could have led to discontent within the team. Unintended consequences of the project included the possibility that an increase in satisfaction could have been seen within the mentor group because of job/personal fulfilment. This was accounted for through the use of mentor surveys six-weeks post-implementation.

\section{Project Plan (Method)}

This Phases of Change Theory was applied to the project implementation and determined to be an excellent fit. Step one (problem diagnosis) was accomplished through a discussion with the director of the quality department, human resources and chief nursing officer. The problem of high turnover related to burnout was identified as the problem. Step two (assessment of change capacity) was accomplished through the use of the Institute of Healthcare Improvement's (IHI) self-assessment tool. The Checklist to Assess Readiness for Implementation (CARI) was also used to assess organizational readiness for project implementation (IHI, n.d.). Step three (resource and motivation assessment) was accomplished through the use of a SWOT analysis. It was determined that although negatives, like a minimal budget and minimal resources, were identified, enough opportunities and strengths existed to oppose the negatives.

Step four (establishing objectives and strategies) was achieved in partnership with the director of the quality department and the director of human resources. The timeline was discussed as well as the short-term and long-term objectives. Step five (role definition of the intervention) was achieved through a literature review and analysis. Common themes in the evidence were identified and recommendations were developed into a plan for implementation. 
Step six and seven (change maintenance and termination of the helping relationship) were achieved simultaneously with the initial implementation of the project. Mentor and protégé pairing occurred as a standard part of new graduate schedule planning and was adopted by the designated unit. The manager and clinical nurse coordinators on the unit agreed to continue the practice with each new cohort.

Mentors were recruited, with the use of a flyer (see Appendix G) and paired with a single mentee (protégé) by the project manager. Once assigned, the mentors met individually with the project manager. A mentor guide (see Appendix H), created by the project manager, was used as a guide for mentor education and also served as a guide designed to lead the mentor in the role. The mentors completed the exercises and followed the steps in the mentor guide in pursuing a relationship with the mentee independently. A survey was sent to the mentees after six weeks to evaluate program effectiveness (see Appendix $\mathrm{H}$ for mentee survey questions).

All steps within this model placed an emphasis on those who were impacted by the change. This was appropriate for the project because it allowed for involvement from the new graduate nurses in the areas of communication skills, rapport building, problem-solving strategies, and creating ways for feedback (Wagner, 2018).

\section{Schedule and Budget}

A minimal budget was available for this project due to financial constraints from the COVID-19 pandemic. Mentor training was projected to cost around $\$ 500$ and was accomplished mostly during working hours. This was done by the project manager. Supplies were estimated to cost around $\$ 600$ and included printing materials, notebook binding, and a $\$ 25$ gift card for each mentor. These costs were supposed to be supplied by both the designated unit and the quality department, however the funding was never supplied because of cost-constraints related 
to the COVID-19 pandemic. The overhead costs to implement and run the program were estimated to be $\$ 1,000$. Because this project was being implemented during clinical hours, the actual cost was minimal. See Table 1 for a visual representation.

\section{Table 1}

Budget
Expenses (per year)
Total: $\$ 2,100$

Training Mentors

$\$ 500$

Supplies (mentor manual, Starbucks gift cards, etc.) $\quad \$ 600$

Cost to run the program (hourly/ salary cost):

$\$ 1,000$

Surveys, presenting, pairing mentor and protégé, training mentors, etc.

Appendix I shows the projected timeline of the project. The first term of capstone was designated for the planning stage of the project and included tasks like meeting with the quality director and educators. Other tasks included the development of the project proposal, development of mentor training and obtaining approval from the executive leadership team as well as the organizational evidence-based practice committee.

During the second term of the capstone project tasks like in-person mentor training, initial survey, presentations to leadership councils, program implementation and maintenance, and the final survey were all planned. In the final term of the capstone, a final presentation to the administrative team took place following data collection, outcome comparison, and evaluation. Appendix J offers a GANTT chart representing objectives and timeline that were met. This chart 
differs from the schedule because it offers a responsible party for each task, responsibilities and expected dates.

\section{Results}

A thorough project proposal was developed and submitted to The University of St. Augustine for Health Sciences’ EBP Project Review Council (EPRC). Following revisions, approval was gained to implement the EBP project at the designated clinical site. The project proposal was then presented to the organization's EBP council, clinical leadership on the unit where the project was being implemented, and to the director of the quality department at the hospital. Approval was gained following each presentation to implement the project.

The recruitment of mentors started with a voluntary application to participate as a mentor. The application was simple and only required the potential mentor to submit a short personal and professional biography. In order to apply for a mentor position, the applicant was required to have at least one-year of experience as an RN. There were no other exclusion criteria. All protégés were enrolled in the program when they began the newly licensed $\mathrm{RN}$ program at the hospital.

Participants consisted of five newly licensed nurses (mentees or protégés) who obtained licensure within six months prior to hire and five experienced nurses (mentors). Two mentees were male, three were female, and all held a Bachelor's of Science in Nursing degree. All five mentors (four females and one male) held at least a Bachelor's of Science in Nursing.

The environment was the same for all participants therefore, no descriptive differentiating information was necessary. The description of the environment can be found in the project settings section of this paper. Survey data was used to determine project success at six weeks. The questions asked to participants were regarding the protégé's intent to leave (see Appendix 
K). Outcome data was determined by the number of protégés who indicated they intended to remain working within the facility at 12 months following their hire date.

Data collection, analyzing, and storage was done by the project manager. The integrity of the process was high because it was collected through the use of Survey Monkey, analyzed by calculating a rate using Intellectus Statistics Software, and stored on a password protected computer. There was no missing data. Each participant completed the survey.

The integrity of the data source was high due to an online survey through the free platform Survey Monkey. A customized survey, that was only accessible with the correct password, was created. The participants were asked to take the survey while separated from coworkers in an effort to eliminate any extraneous influences.

Formative evaluation took place intermittently over the six-week project through informal check-ins with protégés and mentors. This was necessary to determine if the pairs felt as though the program was beneficial and to determine how frequently pairs were meeting and to allow for changes to be made while the project was in motion. Summative evaluation happened at six-weeks after the program initiation, through the use of a survey to determine the protégé's intent to leave within one-year.

No health information was collected or used during this project. Human rights were protected by making mentorship optional for mentors and mentees. The mentees were allowed to help select a mentor, but none requested this. If a pairing was not working, exceptions were to be made to create more successful relationship, but this was not necessary. No identifying information was used in the data collection or description. 


\section{Data Analysis}

Descriptive analysis was used to evaluate the collected data from both surveys. This analysis was done through the utilization of Intellectus Statistics Software. Descriptive statistics was selected because of the small data set and the exploratory method to examine the variables (Intellectus Statistics, 2020). All variables (participants, gender, and question responses) were entered into the software. Descriptive analysis was selected from the available tools and an analysis was automatically performed by the software. Table 2 below displays all categories of measures, benchmarks, and statistical tests used to determine if a significant improvement was achieved. Tables 3, 4, and 5 offer the descriptive analysis results used to evaluate the data.

\section{Table 2}

Measures, Benchmarks and Statistical Tests

\begin{tabular}{|c|c|c|c|}
\hline Category & Measure & Benchmark & Statistical Test \\
\hline Outcome & Intent to leave (percentage) & $\begin{array}{l}</=50 \% \\
\text { (nominal) }\end{array}$ & Descriptive Analysis \\
\hline Process & $\begin{array}{l}\text { Percentage of pairs that } \\
\text { connect weekly outside of } \\
\text { work (virtual or in-person) }\end{array}$ & $\begin{array}{c}100 \% \\
\text { (nominal) }\end{array}$ & N/A \\
\hline Balancing & Staff satisfaction (mentors) & $\begin{array}{l}>/=65 \% \\
\text { (nominal) }\end{array}$ & Descriptive Analysis \\
\hline Sustainability & $\begin{array}{l}\text { Organizational acceptance and } \\
\text { permission to implement } \\
\text { permanently }\end{array}$ & YES & N/A \\
\hline
\end{tabular}




\section{Outcome}

A statistically significant improvement was determined because the intent to leave within 12 months of hire (mentees) was $20 \%$. More importantly, the outcome is considered to be clinically meaningful, or meaningful to the staff, because the intent to leave was less than or equal to $25 \%$. The meaningfulness was determined by considering the baseline turnover rate in 2019 of $41 \%$ (all nurses) and 50\% (newly licensed nurses).

\section{Process}

The process measure benchmark was set at $100 \%$ and this measure was achieved. Each week the pairs were asked to meet either virtually or in-person during the six-week project. The project manager checked-in with the pairs to ensure meetings taking place.

\section{Balancing}

The balancing measure benchmark was set at greater than, or equal to, $65 \%$ staff satisfaction. Through descriptive analysis it was determined the benchmark was successfully achieved by obtaining staff satisfaction of $65 \%$ (mean). Descriptive analysis was used to evaluate the mentor's job satisfaction at the completion of the six-week project by averaging the scores collected through the surveys.

\section{Sustainability}

Organizational acceptance is the benchmark of success for sustainability. This measure is still in progress and has yet to be obtained. Both mentors and mentees (100\%) recommended the program for the future.

\section{Discussion of Data Evaluation}

The data collected determined the intervention effectively impacted the practice problem of high turnover rates that drove this project. This was evidenced by the high rate of intention to 
stay by both mentors and mentees, high rate of mentor satisfaction, and the recommendation of the program by all participants. This post-survey comparison design demonstrated an outcome of decreased burnout among new graduate nurses evidenced by a lower likelihood to resign.

Summary statistics (Appendix L) were calculated for each interval and ratio variable. The observations for job satisfaction among mentors had an average of 6.80 , or $65 \%,(\mathrm{SD}=1.30$, $\mathrm{SE}_{\mathrm{M}}=0.58, \mathrm{Min}=5.00, \operatorname{Max}=8.00$, Skewness $=-0.36$, Kurtosis = -1.37) (Intellectus Statistics, 2020). The skewness was not greater than two in absolute value which means that the variable was not considered to be asymmetrical about its mean. The kurtosis was less than three, meaning the variable's distribution was not markedly different than a normal distribution in its tendency to produce outliers (Westfall \& Henning, 2013).

The mentor job satisfaction rate of $65 \%$ demonstrated the intervention had a positive impact on the group of mentors overall. This balancing outcome was expected to be demonstrated as a by-product of the project as the evidence suggested.

Frequencies and percentages (see Appendix L) were calculated for each nominal and ordinal variable. The most frequently observed categories of "intention to work past 12 month" for mentors were "yes" (60\%) and "no" (40\%). The most frequently observed categories of "intention to work past 12 months" for mentees were "yes" (80\%) and "no" (20\%). The most frequently observed categories of "intention to work past 18 months" for mentees were "yes" $(60 \%)$ and "no" (40\%). The most frequently observed category of "has the mentorship impacted you positively" for mentors was "yes" (100\%). The most frequently observed categories of "has the mentorship impacted your decision to stay" for mentees were "yes" (80\%) and "no" (20\%). The most frequently observed category of "would you recommend the program" for both mentors and mentees was “yes” ( $\mathrm{n}=10,100 \%)$ (Intellectus Statistics, 2020). 
Data demonstrated the intervention of participating in a formal mentorship, as a mentor for six weeks to newly licensed nurses, had a positive impact on the mentors, their job satisfaction, and their intention to continue working on the unit. Data also demonstrated the intervention of being mentored, by an experienced nurse on the unit, positively impacted the newly licensed nurses' intention to continue working on the unit and also demonstrated the mentorship program was recommended by all mentors, and mentees, and that the mentors had an impact on the decision of the mentees to stay or leave.

Two mentees and one mentor indicated, in the comments portion of the survey, the opportunity to participate in a residency program on a specialty unit, offered within the organization, was a reason that they would leave the unit eventually. One mentor indicated they had decided to leave because of a position within the float team that offered higher pay. Three mentors indicated, in the comments portion of the survey, the program could be more successful if the leadership team offered more support. The data displayed a clearly positive relationship between the intervention and the outcome.

\section{Impact}

This project has impacted the problem of high turnover among newly licensed registered nurses in a positive way. The high rate of "intention to stay beyond 12 months of hire," indicated in the collected data, supports the intervention of a formal mentor program. The project addressed the problem by making changes in the working environment through the establishment of relationships (mentorship) between newly licensed RNs and experienced RNs. The project has altered the practice at the designated facility by creating an additional support, in the form of a mentor, for newly licensed RNs. 
A consistently low turnover rate, among newly licensed nurses, is a future implication. This low turnover rate could contribute to greater staff satisfaction overall (Frost et al., 2013; Halfer et al., 2008; Latham et al., 2011; Schroyer et al., 2020), more engaged nurses who provide higher quality care (Berezuik, 2010), and a more cohesive care team. If these can be achieved, and sustained, the larger organization may decide to implement the new practice within all 17 facilities.

In order to further improve the turnover rate among newly licensed RNs, there should be a more thoughtful and in-depth selection process during the hiring process. In the postintervention surveys, two newly licensed RNs indicated that they would eventually leave the unit to seek specialty units like emergency medicine or pediatrics. It is not beneficial to hire an RN who intends to transfer units shortly following hire. The length of the mentorship should also be increased to one full year from the date of hire as this would provide an ongoing relationship after orientation has ended, and would offer support as the newly licensed nurse develops their own practice. This would also offer the newly licensed nurse support in difficult situations that may arise.

In order to maintain sustainability of the program there must be more support from the unit leadership team. Monetary incentives were offered to the mentors to participate in the program, but the leadership team was unable to deliver those incentives. An incentive is needed to attract more experienced nurses to the role of mentor. There would also need to be a person assigned as the long-term coordinator/facilitator. This role is essential for mentor recruitment, proper training for mentors, pairing, scheduling, and evaluation of on-going effectiveness. 


\section{Limitations}

This project has potential limitations. The small data set may not represent true nursing turnover. Due to the small sample size, statistical measurement could not be done utilizing the chi-Squared method. Descriptive analytics was used instead, as recommended by Intellectus Statistics. In the future, it is recommended that a larger data set be used in order to truly represent the newly licensed nurse population and to provide more data to analyze the relationship to the variable. Other limitations include the time constraint of six weeks for implementation and unforeseen pandemic-related restrictions. The time restriction did not allow for participant sampling and surveying at several different points in time to monitor for effectiveness. A future study is recommended to span a longer period of time. This study should also be conducted during a time when the worldwide health crisis has subsided. This would allow for more socializing and gathering as a group, which could impact the results.

\section{Plans for Dissemination}

Dissemination within the organization will occur in different formats aimed at reaching different audiences. The dissemination of findings will first occur with the bedside staff who participated in the mentor program. This will happen through staff meetings and the unit newsletter that is distributed via email every Friday. Dissemination within the hospital will happen in a virtual presentation sent to the hospital's leadership team. This team consists of a nurse manager and director from each unit, the entire executive team, the hospital-wide educator, and the quality team. The information will be presented in a recorded and narrated power point discussed by the project manager. Finally, the information will be offered as a narrative in the hospital's monthly newsletter that is distributed via email to all associates. Dissemination within 
the corporation will occur as a presentation, utilizing the same power point shared with the hospital leadership team.

\section{Professional Sharing}

This project will be shared at the annual EBP conference hosted by the designated organization. The EBP conference is held at Denver University each November. In order to have this project accepted and to earn a position as a presenter, an abstract and a sample of the poster that will be used will be virtually submitted. The University of St. Augustine's SOAR@USA publication platform will be utilized to share this project. The manuscript will also be submitted to MEDSURG Nursing, a nursing journal, for publication.

\section{Peer Review}

Peer review will occur prior to submitting the abstract for consideration as a presentation at the evidence-based conference. The peer review will be done blindly as the reviewers will be asked to review the full project without knowing the author. The preceptor at the designated facility, who is associated with this project, will submit the project to several of her professional colleagues and ask them to do a peer review with comments.

\section{Conclusion}

The intention of this project was to impact the working environment and professional relationships among newly licensed nurses, thus positively impacting the high turnover rate among this population. The intention was achieved successfully, through the implementation of a formal mentorship program, as evidenced by the intentions of the participants to remain working on the unit at least 12 months beyond the date of hire.

Initially, a thorough literature review, analysis, and synthesis was conducted. The implementation of a formal mentorship program was selected based on the supporting evidence. 
Mentors were selected and trained individually using a mentor guide. Program evaluation was completed through the use of anonymous surveys for both mentors and mentees. Data demonstrated a positive impact of the mentorship program for both job satisfaction of the mentors, as well as the turnover rate for the newly licensed nurses. 


\section{References}

Aiken, L., Sermeus, W., Van den Heede, K., Sloane, D., Busse, R., McKee, M., Bruyneel L, Rafferty, A., Griffiths, P., Moreno-Casbas, M., Tishelman, C., Scott, A., Brzostek, T., Kinnunen, J., Schwendimann, R., Heinen, M., Zikos, D., Sjetne, I., Smith, H., \& KutneyLee, A. (2012). Patient safety, satisfaction, and quality of hospital care: Cross sectional surveys of nurses and patients in 12 countries in Europe and the United States. British Medical Journal, 2012(344).

http://doras.dcu.ie/19510/1/Aiken_et_al_2012_bmj.e1717_Patient_safety\%2C_satisfactio n_and_quality_of_care\%281\%29.pdf

Ackley, B. J., Swan, B. A., Ladwig, G., \& Tucker, S. (2008). Evidence-based nursing care guidelines: Medical-surgical interventions. (p. 7). Mosby Elsevier.

Berezuik, S. (2010). Mentoring in emergency care: 'Growing our own.' Emergency Nurse, 18(7), 12-15. DOI: $\underline{\text { 10.7748/en2010.11.18.7.12.c8083 }}$

Bong, H. (2019). Understanding moral distress: How to decrease turnover rates of new graduate pediatric nurses. Pediatric Nursing, 45(3), 109-114. https://www.thefreelibrary.com/Understanding+Moral+Distress\%3A+How+to+Decrease +Turnover+Rates+of+New...-a0592139555

Buckley, L., Christian, M., Gaiteiro, R., Parshuram, C., Watson, S. \& Dryden-Palmer, K. (2019). The relationship between pediatric critical care nurse burnout and attitudes about engaging with patients and families. Canadian Journal of Critical Care Nursing, 30(3), 22-28. https://www.researchgate.net/profile/Laura-Buckley7/publication/340902096_The_relationship_between_pediatric_critical_care_nurse_burn out_and_attitudes_about_engaging_with_patients_and_families/links/5ea32b9d45851553 
faacc35b/The-relationship-between-pediatric-critical-care-nurse-burnout-and-attitudesabout-engaging-with-patients-and-families.pdf

Centura Health (2020). Quality dashboard [pdf].

Chen, C. \& Lou, M. (2013). The effectiveness and application of mentorship programmes for recently registered nurses: A systematic review. Journal of Nursing Management, 22, 433-442. DOI: $\underline{10.1111 / j o n m .12102}$

Choe, K., Kang, Y. \& Park, Y. (2015). Moral distress in critical care nurses: A phenomenological study. Journal of Advanced Nursing, 71(7), 1684-93.

\section{DOI: $10.1111 /$ jan.12638}

Cottingham, S., DiBartolo, M., Battistoni, S. \& Brown, T. (2011). Partners in nursing: A mentoring initiative to enhance nurse retention. Nursing Education Perspectives, 32(4), 250-255. DOI: $\underline{10.5480 / 1536-5026-32.4 .250}$

Dearholt, S. \& Dang, D. (2012). Johns Hopkins nursing evidence-based practice: Models and guidelines. Sigma Theta Tau International.

Fox, K. (2010). Mentor program boosts new nurses' satisfaction and lowers turnover rate. The Journal of Continuing Education in Nursing, 41(7), 311-316. DOI: 10.3928/00220124$\underline{20100401-04}$

Frost, N., Nickolai, L., Desir, S. \& Fairchild, R. (2013). From our readers: How mentorship affects retention rates of new nurses. American Nurse Today, 8(4). http://www.americannursetoday.com/article.aspx?id=10180\&fid=10122

Halfer, D., Graf, E. \& Sullivan, C. (2008). The organizational impact of a new graduate pediatric nurse mentoring program. NURISNG ECONOMIC\$, 26(4). 243-249. https://pubmed.ncbi.nlm.nih.gov/18777973/ 
Institute for Healthcare Improvement [IHI] (n.d.). IHI Improvement Capability Self-Assessment Tool. http://app.ihi.org/FacultyDocuments/Events/Event-2354/Presentation9119/Document-7406/L2_Improvement_Tool.pdf

Intellectus Statistics [Online computer software]. (2020). Intellectus Statistics. https://analyze.intellectusstatistics.com/

Iowa Model Collaborative (2017). Iowa model of evidence-based practice: Revisions and validation. Worldviews on Evidence-Based Nursing, 14(3), 175-182.

DOI: $\underline{10.1111 / \text { wVn. } 12223}$

Kutney-Lee, A., Wu, E., Sloane, D., Aiken, L., \& Fagin, C. (2013). Changes in hospital nurse work environments and nurse job outcomes: An analysis of panel data. International Journal of Nursing Studies, 50(2), 195-201. DOI: 10.1016/j.ijnurstu.2012.07.014

Latham, C., Ringl, K. \& Mikel, H. (2011). Professionalization and retention outcomes of a university-service mentoring program partnership. Journal of Professional Nursing, 27(6), 344-353. DOI: $10.1016 /$ j.profnurs.2011.04.015

Lippitt, R., Watson, J., \& Westley, B. (1958). The dynamics of planned change. Brace \& World.

Lundgren, L., Amodeo, M., Chassler, D., Krull, I., \& Sullivan, L. (2013). Organizational readiness for change in community-based addiction treatment programs and adherence in implementing evidence-based practices: A national study. Journal of Substance Abuse Treatment, 45(5). https://doi.org/10.1016/j.jsat.2013.06.007

Malott, M. (2012). Building nursing capacity. Canadian Journal of Nursing Leadership. 89-98. DOI: $10.12927 / \operatorname{cjn} 1.2012 .22804$ 
Nursing Solutions Inc. (2020). 2020 NSI national health care retention \& RN staffing report. https://www.nsinursingsolutions.com/Documents/Library/NSI_National_Health_Care_R etention_Report.pdf

Palermo, K. (2020). SQUIRE quality tools [scholarly paper].

Rush, K., Adamack, M. Gordon, J., Lilly, M. \& Janke, R. (2012). Best practices of formal new graduate nurse transition programs: An integrative review. International Journal of Nursing Studies, 50, 345-356. DOI: 10.1016/j.ijnurstu.2012.06.009

Sandler, M. (2018). Why are new graduate nurses leaving the profession in their first year of practice and how does this impact on ED nurse staffing? A rapid review of current literature and recommended reading. Canadian Journal of Emergency Nursing, 41(1), 23-24. DOI: https://doi.org/10.29173/cjen66

Schroyer, C., Zellers, R. \& Abraham, S. (2020). Increasing registered nurse retention using mentors in critical care services. The Health Care Manager, 39(2), 85-99. DOI: $10.1097 / \mathrm{HCM} .0000000000000118$

Silvestre, J., Ulrich, B., Johnson, T., Spector, N. \& Blegen, M. (2017). A multisite study on a new graduate registered nurse transition to practice program: Return on investment. Nursing Economic\$, 35(3), 110-118. https://www.ncsbn.org/11857.htm

U.S. Department of Health and Human Services (2011). Quality improvement [pdf]. https://www.hrsa.gov/sites/default/files/quality/toolbox/508pdfs/qualityimprovement.pdf

Wagner, J. (2018). Leadership and influencing change in nursing. University of Regina Press.

Westfall, P. H., \& Henning, K. S. S. (2013). Texts in statistical science: Understanding advanced statistical methods. Taylor \& Francis. 
Williams, F., Scott, E., Tyndall, D. \& Swanson, M. (2018). New nurse graduate residency mentoring: A retrospective cross-sectional research study. NURSING ECONOMIC\$, $36(3), 121-127$. https://go.gale.com/ps/anonymous?id=GALE\%7CA547075576\&sid=googleScholar\&v= 2.1\&it $=\mathrm{r} \&$ linkaccess $=\mathrm{abs} \& \mathrm{issn}=07461739 \& \mathrm{p}=\mathrm{AONE} \& \mathrm{sw}=\mathrm{w}$

Yoo, J. Y., Kim, J. H., Kim, J. S., Kim, H. L., \& Ki, J. S. (2019). Clinical nurses' beliefs, knowledge, organizational readiness and level of implementation of evidence-based practice: The first step to creating an evidence-based practice culture. PLoS ONE, 14(12). https://link.gale.com/apps/doc/A609782046/AONE?u=lirn55718\&sid=AONE\&xid=1c3f $5 \mathrm{~d} 05$

Zhang, Y., Huang, X., Xu, S., Xu, C., Feng, X. \& Jin, J. (2019). Can a non-on-one mentorship program reduce the turnover rate of new graduate nurses in China? A longitudinal study. Nurse Education in Practice, 40, 1-8. DOI: 10.1016/j.nepr.2019.08.010

Zhang, Y., Qian, Y., Wu, J., Wen, F. \& Zhang, Y. (2015). The effectiveness and implementation of mentoring program for newly graduated nurses: A systematic review. Nurse Education Today, 37, 136-144. DOI: 10.1016/j.nedt.2015.11.027 
Appendix A

EBP Model - IOWA Model

\section{The lowa Model Revised: Evidence-Based Practice to Promote Excellence in Health Care}

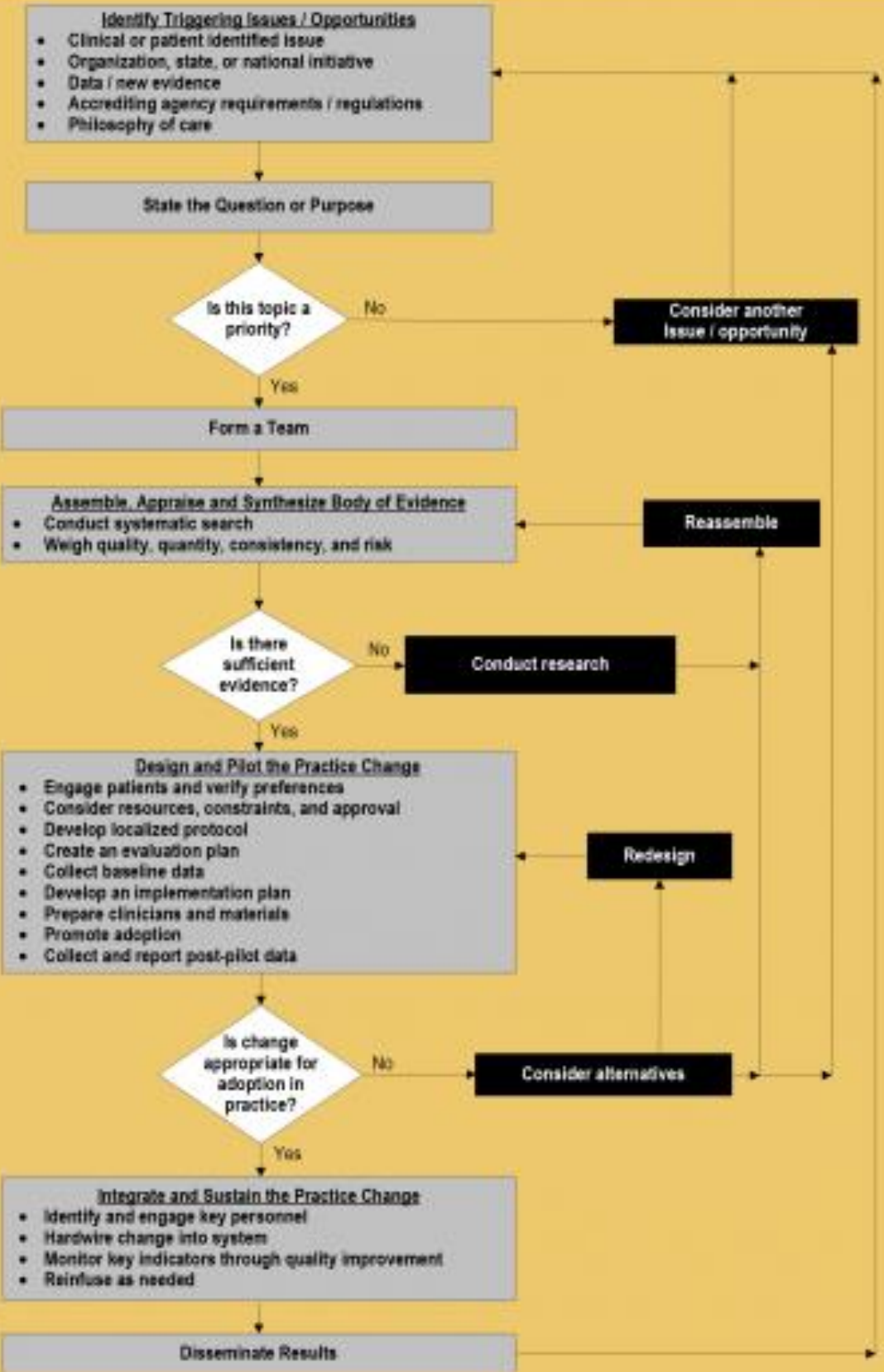


Appendix B

PRISMA Flow Diagram

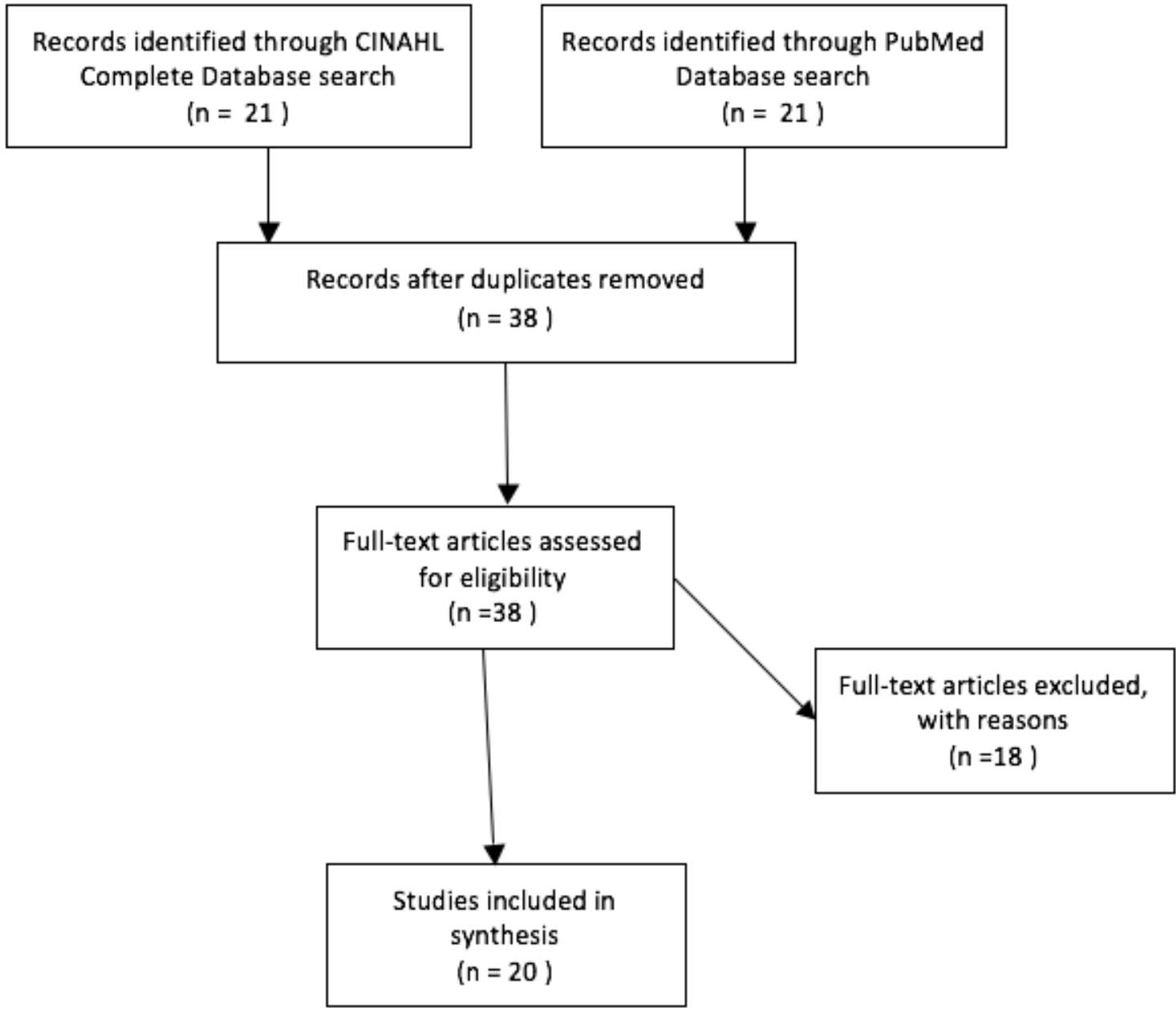


Appendix C

Summary of Primary Research Evidence

\begin{tabular}{|c|c|c|c|c|c|c|}
\hline Citation & $\begin{array}{c}\text { Design \& } \\
\text { Level } \\
\text { Quality } \\
\text { Grade }\end{array}$ & $\begin{array}{c}\text { Sample } \\
\text { Setting } \\
\text { Sample size }\end{array}$ & Intervention & $\begin{array}{l}\text { Theoretical } \\
\text { Foundation (if } \\
\text { discussed) }\end{array}$ & $\begin{array}{l}\text { Outcome } \\
\text { Definition }\end{array}$ & $\begin{array}{c}\text { Results } \\
\text { Key Findings } \\
\text { Usefulness \& Implications }\end{array}$ \\
\hline $\begin{array}{l}\text { Schroyer, C., } \\
\text { Zellers, R. \& } \\
\text { Abraham, S. } \\
\text { (2020). Increasing } \\
\text { registered nurse } \\
\text { retention using } \\
\text { mentors in critical } \\
\text { care services. The } \\
\text { Health Care } \\
\text { Manager, 39(2), } \\
\text { 85-99. }\end{array}$ & $\begin{array}{l}\text { Quasi- } \\
\text { experimental } \\
\text { descriptive } \\
\text { research, } \\
\text { Level II, High } \\
\text { Quality }\end{array}$ & $\begin{array}{l}\text { RNs were from } \\
\text { a } 325 \text { bed acute } \\
\text { care hospital in } \\
\text { Indiana. } \\
32 \text { mentees \& } \\
35 \text { mentors in } \\
\text { the } \\
\text { experimental } \\
\text { group. } 35 \mathrm{RNs} \\
\text { in the control } \\
\text { group. } \\
\text { RNs were from } \\
\text { all inpatient } \\
\text { units. }\end{array}$ & $\begin{array}{l}70 \text { newly hired RNs } \\
\text { were split into } 2 \\
\text { groups. Group } 1 \text { was } \\
\text { assigned an } \\
\text { experienced RN as a } \\
\text { mentor for the first } \\
\text { year and group } 2 \text { was } \\
\text { not assigned a } \\
\text { mentor. } \\
\text { Retrospective review } \\
\text { was done to } \\
\text { determine retention } \\
\text { rates as well as } \\
\text { descriptive surveys. } \\
\mathrm{P}=.009 \text { ( } X^{2} \text { ) proving } \\
\text { the alternate } \\
\text { hypothesis: there is } \\
\text { an association } \\
\text { between mentorship } \\
\text { and retention rates. }\end{array}$ & $\begin{array}{l}\text { Benner's theory } \\
\text { that nurses gain } \\
\text { knowledge, } \\
\text { competence, } \\
\text { confidence, and } \\
\text { comfort in } \\
\text { managing the } \\
\text { tasks of nursing } \\
\text { through the } \\
\text { concept of novice } \\
\text { to expert. }\end{array}$ & $\begin{array}{l}\text { Retention rate } \\
\text { (ratio of } \\
\text { employees who } \\
\text { continue to be } \\
\text { employed after a } \\
\text { certain period) }\end{array}$ & $\begin{array}{l}\text { Positive implications related to using a mentor } \\
\text { program. Nurses with a mentor were retained } \\
\text { at a } 25 \% \text { higher rate than those not mentored. } \\
\text { Control group had a retainment rate of } 66 \% \\
\text { while the experimental group's rate was } 91 \% \text {. } \\
\text { Other potential implications include increased } \\
\text { patient satisfaction and significant } \\
\text { organizational cost savings. }\end{array}$ \\
\hline $\begin{array}{l}\text { Fox, K. (2010). } \\
\text { Mentor program } \\
\text { boosts new nurses' } \\
\text { satisfaction and } \\
\text { lowers turnover } \\
\text { rate. The Journal } \\
\text { of Continuing }\end{array}$ & $\begin{array}{l}\text { Pilot Study. } \\
\text { Level II. } \\
\text { Moderate } \\
\text { Quality. }\end{array}$ & $\begin{array}{l}12 \text { RN pairs } \\
\text { (Mentor \& } \\
\text { Protégé) from } \\
\text { all inpatient } \\
\text { units from St. } \\
\text { Francis } \\
\text { Hospital and }\end{array}$ & $\begin{array}{l}\text { Intervention assigned } \\
\text { a mentor to a protégé } \\
\text { for a 12-month long } \\
\text { mentorship. This } \\
\text { mentorship consisted } \\
\text { of face-to-face } \\
\text { meetings, paired }\end{array}$ & Not discussed. & $\begin{array}{l}\text { Turnover rate } \\
\text { (ratio of } \\
\text { employees who } \\
\text { voluntarily leave } \\
\text { their position) for } \\
\text { both newly }\end{array}$ & $\begin{array}{l}0 \% \text { turnover from the } 1^{\text {st }} \text { year of the program } \\
\text { demonstrates that mentors can positively } \\
\text { impact the turnover rate. After the } 1^{\text {st }} \text { year the } \\
\text { turnover rate for newly licensed RNs dropped } \\
\text { from } 31 \% \text { to } 10.3 \% \text { and for all other RNs it } \\
\text { dropped from } 32 \% \text { to } 10.3 \% \text {. }\end{array}$ \\
\hline
\end{tabular}




\begin{tabular}{|c|c|c|c|c|c|c|}
\hline $\begin{array}{l}\text { Education in } \\
\text { Nursing, } 41(7), \\
311-316 .\end{array}$ & & $\begin{array}{l}\text { Health Centers } \\
\text { in Indiana. }\end{array}$ & $\begin{array}{l}\text { schedules, reports, } \\
\text { evaluations and } \\
\text { meetings off-campus. } \\
\text { Training for mentors } \\
\text { was in depth and } \\
\text { required. }\end{array}$ & & $\begin{array}{l}\text { licensed RNs and } \\
\text { mentor RNs. }\end{array}$ & $\begin{array}{l}\text { Mentors provide an additional layer of support } \\
\text { and resources which lead to increased comfort } \\
\text { for new nurses. }\end{array}$ \\
\hline $\begin{array}{l}\text { Williams, F., } \\
\text { Scott, E., Tyndall, } \\
\text { D. \& Swanson, M. } \\
\text { (2018). New } \\
\text { nurse graduate } \\
\text { residency } \\
\text { mentoring: A } \\
\text { retrospective } \\
\text { cross-sectional } \\
\text { research study. } \\
\text { NURSING } \\
\text { ECONOMIC\$, } \\
\text { 36(3), 121-127. }\end{array}$ & $\begin{array}{l}\text { Retrospective } \\
\text { cross- } \\
\text { sectional } \\
\text { research } \\
\text { study. } \\
\text { Level } 3 . \\
\text { High Quality. }\end{array}$ & $\begin{array}{l}3,484 \text { new } \\
\text { graduate nurses } \\
\text { from } 102 \\
\text { hospitals in } 24 \\
\text { hospital } \\
\text { systems in } 14 \\
\text { states. }\end{array}$ & $\begin{array}{l}\text { Mentors were } \\
\text { assigned without } \\
\text { compatibility } \\
\text { assessment to those } \\
\text { participating in The } \\
\text { Versant RN } \\
\text { residency program. } \\
\text { Two evaluation } \\
\text { surveys were used } \\
\text { for all participants. } \\
X^{2} \text { was used to } \\
\text { calculate probability. } \\
\text { SPSS } 24 \text { was used to } \\
\text { analyze descriptive } \\
\text { and inferential } \\
\text { statistics. }\end{array}$ & Not discussed. & $\begin{array}{l}\text { Rate of intention to } \\
\text { leave their job } \\
\text { (collected by } \\
\text { survey). }\end{array}$ & $\begin{array}{l}95.3 \% \text { of those who had a } 1: 1 \text { mentor had } \\
\text { no/low intention to leave. } 93.8 \% \text { of those who } \\
\text { participated in a group with one mentor had } \\
\text { no/low intention to leave. Those who had a } \\
1: 1 \text { mentor reported that the mentor was } \\
\text { helpful to them in their transition to practice, } \\
\text { professional development, and stress } \\
\text { management. }\end{array}$ \\
\hline $\begin{array}{l}\text { Halfer, D., Graf, } \\
\text { E. \& Sullivan, C. } \\
\text { (2008). The } \\
\text { organizational } \\
\text { impact of a new } \\
\text { graduate pediatric } \\
\text { nurse mentoring } \\
\text { program. } \\
\text { NURSING } \\
\text { ECONOMIC\$, } \\
26(4) .243-249 .\end{array}$ & $\begin{array}{l}\text { Descriptive } \\
\text { study. } \\
\text { Level } 3 . \\
\text { Moderate } \\
\text { Quality. }\end{array}$ & $\begin{array}{l}270 \text { bed } \\
\text { Midwestern, } \\
\text { urban, magnet } \\
\text { facility } \\
\text { specializing in } \\
\text { pediatrics. } 84 \\
\text { newly licensed } \\
\text { nurses in the } \\
\text { pre- } \\
\text { implementation } \\
\text { group. } 212 \\
\text { newly licensed } \\
\text { nurses in the } \\
\text { post- } \\
\text { implementation } \\
\text { group. }\end{array}$ & $\begin{array}{l}\text { Comparison of two } \\
\text { cohorts of new } \\
\text { graduate nurses: one } \\
\text { before and one after } \\
\text { the implementation } \\
\text { of an internship } \\
\text { program that had a } \\
\text { formal mentorship } \\
\text { component }\end{array}$ & Not discussed. & $\begin{array}{l}\text { Descriptive } \\
\text { Survey. } \\
\text { The job } \\
\text { satisfaction tool } \\
\text { was developed by } \\
\text { the investigators } \\
\text { and comprised } \\
\text { demographic fill-in } \\
\text { blanks, a Likert- } \\
\text { type scale seeking } \\
\text { degree of } \\
\text { agreement for } 21 \\
\text { statements and } 4 \\
\text { open-ended } \\
\text { questions. }\end{array}$ & $\begin{array}{l}\text { 1-year voluntary turnover was } 12 \% \text { average } \\
\text { per class compared to the pre-implementation } \\
\text { group's rate of } 20 \% \text {. } \\
\text { Improved job satisfaction was also reflected in } \\
\text { a lower turnover rate that was sustained during } \\
\text { the } 2 \text {-year post-intervention study period. By } \\
\text { lowering turnover rates, organizations avoid } \\
\text { costs associated with recruitment, orientation, } \\
\text { and temporary labor coverage or vacant RN } \\
\text { positions. } \\
\text { The implications are that there is a need for } \\
\text { more longitudinal studies. }\end{array}$ \\
\hline
\end{tabular}




\begin{tabular}{|c|c|c|c|c|c|c|}
\hline $\begin{array}{l}\text { Cottingham, S., } \\
\text { DiBartolo, M., } \\
\text { Battistoni, S. \& } \\
\text { Brown, T. (2011). } \\
\text { Partners in } \\
\text { nursing: A } \\
\text { mentoring } \\
\text { initiative to } \\
\text { enhance nurse } \\
\text { retention. Nursing } \\
\text { Education } \\
\text { Perspectives, } \\
\text { 32(4), 250-255. }\end{array}$ & $\begin{array}{l}\text { Pilot study. } \\
\text { Level II. } \\
\text { Moderate } \\
\text { Quality } \\
\text { (sample size) }\end{array}$ & $\begin{array}{l}21 \text { mentor } \\
\text { RNs, } 19 \\
\text { protégé RNs at } \\
\text { The } \\
\text { Community } \\
\text { Foundation of } \\
\text { the Eastern } \\
\text { Shore in } \\
\text { Salisbury, } \\
\text { Maryland } \\
\text { (spread across } \\
3 \text { area } \\
\text { hospitals). }\end{array}$ & $\begin{array}{l}\text { Newly graduated } \\
\text { RNs (protégés) were } \\
\text { paired with } \\
\text { experienced RN } \\
\text { mentors during the } \\
\text { protégé's first year of } \\
\text { work. Program } \\
\text { consisted of a } \\
\text { monthly gathering } \\
\text { and educational } \\
\text { seminar. Continuous } \\
\text { professional } \\
\text { development. }\end{array}$ & Not discussed. & $\begin{array}{l}\text { Single-paged tools } \\
\text { called "interaction } \\
\text { worksheets" were } \\
\text { used that } \\
\text { addressed clinical } \\
\text { skills, social } \\
\text { skills/relationships, } \\
\text { problem solving, } \\
\text { self-esteem, } \\
\text { dealing with } \\
\text { failure, and } \\
\text { accessing } \\
\text { organizational } \\
\text { resources. Space } \\
\text { was left for } \\
\text { additional } \\
\text { qualitative } \\
\text { feedback. Other } \\
\text { online surveys } \\
\text { were used to } \\
\text { determine the } \\
\text { value of sessions. }\end{array}$ & $\begin{array}{l}\text { Participant satisfaction with the program was } \\
100 \% \text {. Retention of newly licensed nurses was } \\
100 \% \text {. Intention to stay working as an RN was } \\
100 \% \text {. The Partners in Nursing program } \\
\text { increased retention rates by use of formalized } \\
\text { mentor process and cultivated leadership } \\
\text { potential, opportunities for professional } \\
\text { development, and community outreach. }\end{array}$ \\
\hline $\begin{array}{l}\text { Latham, C., Ringl, } \\
\text { K. \& Mikel, H. } \\
\text { (2011). } \\
\text { Professionalization } \\
\text { and retention } \\
\text { outcomes of a } \\
\text { university-service } \\
\text { mentoring } \\
\text { program } \\
\text { partnership. } \\
\text { Journal of } \\
\text { Professional } \\
\text { Nursing, 27(6), } \\
\text { 344-353. }\end{array}$ & $\begin{array}{l}\text { Quasi- } \\
\text { experimental } \\
\text { with pre/post } \\
\text { tests. } \\
\text { Level II, High } \\
\text { Quality }\end{array}$ & $\begin{array}{l}89 \text { newly } \\
\text { licensed RNs } \\
\& 109 \text { mentor } \\
\text { RNs from } 2 \\
\text { acute care } \\
\text { hospitals in the } \\
\text { southwest } \\
\text { region over a } \\
1-3 \text { year time } \\
\text { period. }\end{array}$ & $\begin{array}{l}\text { Non-control group } \\
\text { pre/post test design. } \\
\text { Comparison of data } \\
\text { was pre-intervention } \\
\text { data. Mentees } \\
\text { selected a mentor } \\
\text { based off of profiles. } \\
\text { Mentors attended } 2 \\
\text { eight-hour courses } \\
\text { learning necessary } \\
\text { mentoring skills. } \\
\text { Formal meetings and } \\
\text { paired schedules for } \\
\text { mentor/mentee. } \\
\text { Relationship } \\
\text { consisted of } \\
\text { feedback/evaluations, }\end{array}$ & Not discussed. & $\begin{array}{l}\text { Baseline collection } \\
\text { of perceptions of } \\
\text { occupational } \\
\text { stress, cultural } \\
\text { competence, } \\
\text { personality type } \\
\text { and learning style. } \\
\text { These measures } \\
\text { were repeated at } 3 \\
\text { years. Similar } \\
\text { inventories and } \\
\text { questionnaires } \\
\text { were used for all } \\
\text { sections (Likert- } \\
\text { scaled). } \\
\text { Vacancy was } \\
\text { defined as the }\end{array}$ & $\begin{array}{l}\text { Vacant RN positions at one hospital decreased } \\
\text { by } 80 \% .21 \% \text { retention rate improvement at } \\
\text { the other hospital ( } 76 \% \text { to } 91.72 \%) \text {. } \\
\text { Qualitative data identified many existing issues } \\
\text { and positives for a mentor program. A mentor } \\
\text { program with comprehensive education and } \\
\text { mentor/management alliance enhances } \\
\text { professionalism and helps to sustain a positive } \\
\text { and constructive workplace environment. } \\
\text { Mentoring increases support for newly } \\
\text { licensed RNs and offered an informal } \\
\text { leadership role for staff nurses. }\end{array}$ \\
\hline
\end{tabular}




\begin{tabular}{|c|c|c|c|c|c|c|}
\hline & & & $\begin{array}{l}\text { reflection, } \\
\text { communication, } \\
\text { education and an } \\
\text { informal relationship. }\end{array}$ & & $\begin{array}{l}\text { number of open } \\
\text { requisitions } \\
\text { divided by the } \\
\text { number of open } \\
\text { requisitions and } \\
\text { currently } \\
\text { employed RNs. } \\
\text { Retention was } \\
\text { defined as the total } \\
\text { number of RN } \\
\text { separations divided } \\
\text { by } 1 \text { minus total } \\
\text { number of RN } \\
\text { employees. }\end{array}$ & \\
\hline $\begin{array}{l}\text { Zhang, Y., Huang, } \\
\text { X., Xu, S., Xu, C., } \\
\text { Feng, X. \& Jin, J. } \\
\text { (2019). Can a } \\
\text { non-on-one } \\
\text { mentorship } \\
\text { program reduce } \\
\text { the turnover rate } \\
\text { of new graduate } \\
\text { nurses in China? A } \\
\text { longitudinal study. } \\
\text { Nurse Education } \\
\text { in Practice, 40, 1- } \\
\text { 8. }\end{array}$ & $\begin{array}{l}\text { Non- } \\
\text { randomized } \\
\text { control study. } \\
\text { Level 1. } \\
\text { High Quality. }\end{array}$ & $\begin{array}{l}\text { New graduate } \\
\text { nurses (NGN) } \\
\text { from with } \\
\text { Bachelors } \\
\text { degree. In } \\
2013 \text { the } \\
\text { control group } \\
\text { consisted of } \\
199 \text { NGNs. In } \\
2014 \text { the } \\
\text { experimental } \\
\text { group } \\
\text { consisted of } \\
239 \text { NGNs. } \\
\text { Tertiary } \\
\text { general } \\
\text { hospital } \\
\text { located in } \\
\text { China (3200 } \\
\text { beds on } 2 \\
\text { campuses). } \\
\text { Data was } \\
\text { analyzed using } \\
\text { SPSS } 22.0 \text { and }\end{array}$ & $\begin{array}{l}\text { NGNs recruited in } \\
2013 \text { (control group) } \\
\text { were given a basic } \\
\text { preceptorship. } \\
\text { NGNs recruited in } \\
2014 \text { were included } \\
\text { in a one-on-one } \\
\text { mentorship program. } \\
\text { Asynchronous } \\
\text { comparison was used } \\
\text { to avoid } \\
\text { contamination } \\
\text { between the two } \\
\text { groups. PASS15.0 } \\
\text { was used to calculate } \\
\text { the sample size, } \\
\text { differences between } \\
\text { turnover rates, using } \\
\text { a log-ran test. } \\
\text { Mentorship lasted for } \\
\text { one full year and } \\
\text { activities included } \\
\text { teaching, sponsoring, } \\
\text { encouraging, }\end{array}$ & Not discussed. & $\begin{array}{l}\text { Turnover Rate } \\
\text { (calculated during } \\
\text { each of the } 3 \text { years } \\
\text { of the study). }\end{array}$ & $\begin{array}{l}\text { Experimental group }(2013) \text { turnover rates at } 1- \\
\text { year }(2014)=3.77 \%, 2 \text {-year }(2015)=3.48 \% \text {, } \\
3 \text {-year }(2015)=8.11 \% \text {. Control group }(2012) \\
\text { turnover rates at } 1 \text {-year }(2013)=14.07 \%, 2- \\
\text { year }(2014)=9.36 \%, 3 \text {-year }(2015)=14.19 \% \text {. } \\
\text { One-on-one mentorship program is beneficial } \\
\text { for retention of NGNs in the } 1^{\text {st }} \text { year in } \\
\text { particular. }\end{array}$ \\
\hline
\end{tabular}




\begin{tabular}{|c|c|c|c|c|c|c|}
\hline & & $\begin{array}{l}\text { tested using } \\
\text { chi-squared. }\end{array}$ & $\begin{array}{l}\text { counseling, and } \\
\text { befriending. Career } \\
\text { planning was } \\
\text { individualized. }\end{array}$ & & & \\
\hline $\begin{array}{l}\text { Frost, N., } \\
\text { Nickolai, L., } \\
\text { Desir, S. \& } \\
\text { Fairchild, R. } \\
\text { (2013). From our } \\
\text { readers: How } \\
\text { mentorship affects } \\
\text { retention rates of } \\
\text { new nurses. } \\
\text { American Nurse } \\
\text { Today, } 8(4) \text {. }\end{array}$ & $\begin{array}{l}\text { Opinion } \\
\text { paper. } \\
\text { Level } 4 . \\
\text { Low quality. }\end{array}$ & N/A & $\mathrm{N} / \mathrm{A}$ & Not discussed. & N/A & $\begin{array}{l}\text { Through the development of a mentoring } \\
\text { program and implementation of educational } \\
\text { lessons on lateral violence, new graduate } \\
\text { nurses can be retained in the workforce, } \\
\text { resulting in positive outcomes for not only the } \\
\text { patient, but the new graduate nurse as well. } \\
\text { Mentoring is an opportunity for organizations } \\
\text { to demonstrate their commitment to change } \\
\text { and reap positive effects through increased } \\
\text { nursing job satisfaction, decreased nurse } \\
\text { turnover, and positive organizational loyalty. }\end{array}$ \\
\hline $\begin{array}{l}\text { Berezuik, S. } \\
\text { (2010). Mentoring } \\
\text { in emergency care: } \\
\text { 'Growing our } \\
\text { own.' Emergency } \\
\text { Nurse, } 18(7), 12- \\
15 .\end{array}$ & $\begin{array}{l}\text { Opinion } \\
\text { paper/personal } \\
\text { experience. } \\
\text { Level } 5 . \\
\text { Low quality. }\end{array}$ & N/A & N/A & $\begin{array}{l}\text { Benner's Novice } \\
\text { to Expert. } \\
\text { Butler and Felts' } \\
\text { Growing our own. }\end{array}$ & N/A & $\begin{array}{l}\text { New graduates can become competent and } \\
\text { efficient nurses if they are guided by mentors. } \\
\text { Mentoring arrangements can provide new } \\
\text { graduates with the support they need to make } \\
\text { the transition from novice to expert. } \\
\text { Mentoring can transform work environments } \\
\text { and empower nurses. Experienced nurses can } \\
\text { gain a sense of purpose. New graduates can } \\
\text { build relationships with senior staff and can } \\
\text { develop a sense of belonging and contribution. }\end{array}$ \\
\hline $\begin{array}{l}\text { Malott, M. (2012). } \\
\text { Building nursing } \\
\text { capacity. } \\
\text { Canadian Journal } \\
\text { of Nursing } \\
\text { Leadership. 89-98 }\end{array}$ & $\begin{array}{l}\text { Pilot study. } \\
\text { Level II. } \\
\text { Low Quality } \\
\text { (reliability not } \\
\text { discussed) }\end{array}$ & $\begin{array}{l}\text { 35-bed hospital } \\
\text { in Iqaluit, } \\
\text { Nunavut (arctic } \\
\text { Canada). } 26 \\
\text { RNs. }\end{array}$ & $\begin{array}{l}\text { Mentorship program } \\
\text { was implemented to } \\
\text { support new } \\
\text { graduates through } \\
\text { their transition to } \\
\text { work. } 8 \text { experienced } \\
\text { nurses became } \\
\text { mentors and received } \\
\text { specialized training } \\
\text { and mentor manual. }\end{array}$ & Not discussed. & $\begin{array}{l}\text { Nursing } \\
\text { satisfaction (Likert } \\
\text { scale). } \\
\text { Retention Rate. }\end{array}$ & $\begin{array}{l}\text { Through an in-house mentorship program } \\
\text { many professional development opportunities } \\
\text { were created (in-services \& work/study). } \\
\text { Nursing satisfaction increased by } 11 \% \text { during } \\
\text { the duration of the program. Nurses reported } \\
\text { the feeling of developed leadership and clinical } \\
\text { skills. Given the timeframe it was not possible } \\
\text { to measure the retention rate of the new nurses. }\end{array}$ \\
\hline
\end{tabular}




\begin{tabular}{|l|l|l|l|l|}
\hline & & $\begin{array}{l}\text { One-on-one } \\
\text { mentorship for the 1st } \\
6 \text { months. Mentors } \\
\text { and protégés met } \\
\text { once per week. } \\
\text { Group mentoring } \\
\text { was also } \\
\text { incorporated once } \\
\text { per month where one } \\
\text { RN met with all } \\
\text { protégés. }\end{array}$ & & \\
& & & & \\
\end{tabular}


Appendix D

Summary of Systematic Reviews (SR)

\begin{tabular}{|c|c|c|c|c|c|c|c|}
\hline Citation & $\begin{array}{l}\text { Quality } \\
\text { Grade }\end{array}$ & Question/Aim & Search Strategy & $\begin{array}{l}\text { Inclusion/ } \\
\text { Exclusion Criteria }\end{array}$ & $\begin{array}{l}\text { Data Extraction } \\
\text { and Analysis }\end{array}$ & Key Findings & $\begin{array}{l}\text { Usefulness/Rec } \\
\text { ommendation/ } \\
\text { Implications }\end{array}$ \\
\hline $\begin{array}{l}\text { Chen, C. \& Lou, M. } \\
\text { (2013). The } \\
\text { effectiveness and } \\
\text { application of } \\
\text { mentorship } \\
\text { programmes for } \\
\text { recently registered } \\
\text { nurses: A } \\
\text { systematic review. } \\
\text { Journal of Nursing } \\
\text { Management, 22, } \\
\text { 433-442. }\end{array}$ & Level 1. & \begin{tabular}{|l|} 
To conduct a \\
systematic \\
literature \\
review and to \\
examine the \\
effectiveness \\
and application \\
of mentorship \\
programmes for \\
recently \\
registered \\
nurses. \\
\end{tabular} & $\begin{array}{l}\text { Medline, } \\
\text { Cochrane Library, } \\
\text { CINAHL, } \\
\text { PubMed and } 2 \\
\text { international } \\
\text { databases were } \\
\text { used with the } \\
\text { terms } \\
\text { "'mentorship, } \\
\text { mentor, mentor } \\
\text { experience, } \\
\text { preceptor, skill } \\
\text { development, } \\
\text { nursing wisdom, } \\
\text { recently } \\
\text { registered nurse, } \\
\text { new staff nurse, } \\
\text { new graduate } \\
\text { nurse, and novice } \\
\text { nurse." }\end{array}$ & $\begin{array}{l}\text { Includes articles from } \\
1999-2011 . \text { Original } \\
\text { studies only. One-to- } \\
\text { one programs only. } \\
\text { Experimental and } \\
\text { quasi-experimental } \\
\text { studies only. Peer } \\
\text { reviewed only. } \\
\text { Excluded review } \\
\text { articles and studies that } \\
\text { have employed } \\
\text { multiple nursing } \\
\text { interventions. }\end{array}$ & $\begin{array}{l}144 \text { studies } \\
\text { reviewed by } 2 \\
\text { authors and } \\
\text { reached a } \\
\text { consensus on all } \\
\text { articles. Strength } \\
\text { of evidence from } \\
\text { various types of } \\
\text { studies proposed } \\
\text { by Newman and } \\
\text { Roberts were } \\
\text { adopted as the } \\
\text { standard for } \\
\text { critical appraisal. } \\
\text { Finally, five } \\
\text { studies were } \\
\text { selected using } \\
\text { EndNote. }\end{array}$ & $\begin{array}{l}\text { The implementation } \\
\text { of mentorship } \\
\text { programmes } \\
\text { reduced turnover } \\
\text { rates, employee } \\
\text { turnover costs and } \\
\text { medical negligence } \\
\text { rates. Job } \\
\text { satisfaction and } \\
\text { professional identity } \\
\text { were improved. }\end{array}$ & $\begin{array}{l}\text { Mentorship } \\
\text { programmes are } \\
\text { a beneficial } \\
\text { process for } \\
\text { mentors and } \\
\text { recently } \\
\text { registered } \\
\text { nurses. They } \\
\text { involve multi- } \\
\text { dimensional } \\
\text { teaching } \\
\text { strategies and } \\
\text { training courses } \\
\text { and require } \\
\text { long-term } \\
\text { development. }\end{array}$ \\
\hline $\begin{array}{l}\text { Zhang, Y., Qian, } \\
\text { Y., Wu, J., Wen, F. } \\
\& \text { Zhang, Y. } \\
\text { (2015). The } \\
\text { effectiveness and }\end{array}$ & Level 1. & $\begin{array}{l}\text { To evaluate the } \\
\text { effectiveness of } \\
\text { a mentoring } \\
\text { program on the } \\
\text { mentor, mentee, }\end{array}$ & $\begin{array}{l}\text { The Cochrane } \\
\text { Library, Medline, } \\
\text { Ovid, Elsevier, } \\
\text { Embase, } \\
\text { CONAHL, CBM, }\end{array}$ & $\begin{array}{l}\text { Includes studies in } \\
\text { Chinese or English up } \\
\text { until } 2014 \text {. } \\
\text { Inclusion of articles } \\
\text { that targeted newly }\end{array}$ & $\begin{array}{l}146 \text { study } \\
\text { abstracts were } \\
\text { reviewed by } 2 \\
\text { reviewers. Full } \\
\text { text review was }\end{array}$ & \begin{tabular}{|l} 
Turnover can be \\
decreased through a \\
mentoring program. \\
Mentoring can \\
enhance nursing
\end{tabular} & $\begin{array}{l}\text { A successful } \\
\text { mentoring } \\
\text { program should } \\
\text { include rigorous } \\
\text { mentor selection }\end{array}$ \\
\hline
\end{tabular}




\begin{tabular}{|c|c|c|c|c|c|c|c|}
\hline Citation & $\begin{array}{l}\text { Quality } \\
\text { Grade }\end{array}$ & Question/Aim & Search Strategy & $\begin{array}{l}\text { Inclusion/ } \\
\text { Exclusion Criteria }\end{array}$ & $\begin{array}{l}\text { Data Extraction } \\
\text { and Analysis }\end{array}$ & Key Findings & $\begin{array}{l}\text { Usefulness/Rec } \\
\text { ommendation/ } \\
\text { Implications }\end{array}$ \\
\hline $\begin{array}{l}\text { implementation of } \\
\text { mentoring program } \\
\text { for newly graduated } \\
\text { nurses: A } \\
\text { systematic review. } \\
\text { Nurse Education } \\
\text { Today, 37, 136- } \\
144 .\end{array}$ & & $\begin{array}{l}\text { and } \\
\text { organization. }\end{array}$ & $\begin{array}{l}\text { CNKI, and } \\
\text { WanFang Data } \\
\text { databases were } \\
\text { searched using } \\
\text { the terms "newly } \\
\text { graduate nurse, } \\
\text { new graduate } \\
\text { nurse, new nurse } \\
\text { graduate, newly } \\
\text { qualified nurse, } \\
\text { newly registered } \\
\text { nurse, novice } \\
\text { nurse, new nurse, } \\
\text { mentor, } \\
\text { mentoring, } \\
\text { mentorship, } \\
\text { transition and } \\
\text { orientation." }\end{array}$ & $\begin{array}{l}\text { graduated nurses, } \\
\text { experimental or quasi- } \\
\text { experimental design } \\
\text { and those that } \\
\text { contained sufficient } \\
\text { detail about the } \\
\text { mentorship program. } \\
\\
\end{array}$ & \begin{tabular}{|l|} 
done on remaining \\
36 articles. \\
9 articles included \\
in review. Data \\
was extracted \\
using a standard \\
data extraction \\
checklist. All \\
disagreements \\
were discussed \\
with a third \\
review author. \\
Meta-analysis was \\
not done due to \\
the lack of \\
outcome \\
measurements and \\
because most \\
studies were \\
quasi- \\
experimental.
\end{tabular} & $\begin{array}{l}\text { competency and } \\
\text { establish a } \\
\text { supportive } \\
\text { workforce } \\
\text { environment, } \\
\text { resulting in positive } \\
\text { outcomes. } \\
\\
\end{array}$ & $\begin{array}{l}\text { and adequate } \\
\text { training. } \\
\text { Potential } \\
\text { barriers include } \\
\text { time constraints } \\
\text { and scheduling } \\
\text { limitations. } \\
\text { These should be } \\
\text { taken into } \\
\text { consideration } \\
\text { before } \\
\text { implementing. }\end{array}$ \\
\hline \begin{tabular}{|l|} 
Rush, K., \\
Adamack, M. \\
Gordon, J., Lilly, \\
M. \& Janke, R. \\
(2012). Best \\
practices of formal \\
new graduate nurse \\
transition
\end{tabular} & Level 2. & \begin{tabular}{|l|} 
To identify best \\
practices of \\
formal new \\
graduate nurse \\
transition \\
programs.
\end{tabular} & $\begin{array}{l}\text { Literature search } \\
\text { using PubMed, } \\
\text { CINAHL, and } \\
\text { Embase yielding } \\
159 \text { articles. } \\
\text { Hand searching of } \\
\text { reference lists }\end{array}$ & $\begin{array}{l}\text { Terms used were "new } \\
\text { nurse graduates, and } \\
\text { either transition } \\
\text { programs or orientation } \\
\text { programs. English } \\
\text { studies published } \\
\text { between } 2000 \text { and } \\
2011 .\end{array}$ & \begin{tabular}{|l||} 
Cooper's five- \\
stage approach to \\
integrative review \\
guided the process \\
(47 articles). \\
Transition \\
program literature \\
was examined \\
\end{tabular} & $\begin{array}{l}\text { The length, type of } \\
\text { education, and } \\
\text { supports provided } \\
\text { varied considerably } \\
\text { among programs. } \\
\text { The presence of a } \\
\text { transition program } \\
\text { resulted in improved }\end{array}$ & \begin{tabular}{|l|} 
New graduate \\
education should \\
focus on \\
practical skill \\
development, \\
preceptors \\
should receive a \\
level of formal
\end{tabular} \\
\hline
\end{tabular}




\begin{tabular}{|c|c|c|c|c|c|c|c|}
\hline Citation & $\begin{array}{l}\text { Quality } \\
\text { Grade }\end{array}$ & Question/Aim & Search Strategy & $\begin{array}{l}\text { Inclusion/ } \\
\text { Exclusion Criteria }\end{array}$ & $\begin{array}{l}\text { Data Extraction } \\
\text { and Analysis }\end{array}$ & Key Findings & $\begin{array}{l}\text { Usefulness/Rec } \\
\text { ommendation/ } \\
\text { Implications }\end{array}$ \\
\hline $\begin{array}{l}\text { programs: An } \\
\text { integrative review. } \\
\text { International } \\
\text { Journal of Nursing } \\
\text { Studies, 50, 345- } \\
356 .\end{array}$ & & & $\begin{array}{l}\text { from these papers } \\
\text { was conduced } \\
\text { also to ensure all } \\
\text { relevant papers } \\
\text { were included in } \\
\text { the review, } \\
\text { adding } 4 \\
\text { additional papers. }\end{array}$ & $\begin{array}{l}\text { Inclusion: empirical } \\
\text { research, with abstract, } \\
\text { targeted new grads, } \\
\text { contained sufficient } \\
\text { detail, and focused on } \\
\text { acute care setting. } \\
\text { Exclusion: programs } \\
\text { geared toward pre- } \\
\text { registration students, } \\
\text { editorials, gray } \\
\text { literature, residential, } \\
\text { rural or community } \\
\text { settings, specialty } \\
\text { nursing areas. }\end{array}$ & $\begin{array}{l}\text { according to four } \\
\text { major themes. }\end{array}$ & $\begin{array}{l}\text { new graduate nurse } \\
\text { retention and cost } \\
\text { benefits. }\end{array}$ & $\begin{array}{l}\text { training, formal } \\
\text { support should } \\
\text { be available } \\
\text { through the first } \\
6-9 \text { months. } \\
\text { Opportunities } \\
\text { for connection } \\
\text { with peers } \\
\text { should be } \\
\text { offered and } \\
\text { organizations } \\
\text { should strive to } \\
\text { ensure clinical } \\
\text { units with } \\
\text { healthy work } \\
\text { environments. }\end{array}$ \\
\hline
\end{tabular}




\section{Appendix E}

\section{Levels of Evidence Grading and Descriptions}

\begin{tabular}{|c|c|}
\hline Level of Evidence & Types of Studies \\
\hline Level I & $\begin{array}{l}\text { Experimental study, randomized controlled trial }(\mathrm{RCT}) \\
\text { Systematic review of RCTs, with or without meta-analysis }\end{array}$ \\
\hline Level II & $\begin{array}{l}\text { Quasi-experimental Study } \\
\text { Systematic review of a combination of RCTs and quasi-experimental, or quasi- } \\
\text { experimental studies only, with or without meta-analysis. }\end{array}$ \\
\hline Level III & $\begin{array}{l}\text { Non-experimental study } \\
\text { Systematic review of a combination of RCTs, quasi-experimental and non- } \\
\text { experimental, or non-experimental studies only, with or without meta-analysis. } \\
\text { Qualitative study or systematic review, with or without meta-analysis }\end{array}$ \\
\hline Level IV & $\begin{array}{l}\text { Opinion of respected authorities and/or nationally recognized expert } \\
\text { committees/consensus panels based on scientific evidence. } \\
\text { Includes: } \\
\text { - Clinical practice guidelines } \\
\text { - Consensus panels }\end{array}$ \\
\hline Level V & $\begin{array}{l}\text { Based on experiential and non-research evidence. } \\
\text { Includes: } \\
\text { - Literature reviews } \\
\text { - Quality improvement, program or financial evaluation } \\
\text { - Case reports } \\
\text { - Opinion of nationally recognized expert(s) based on experiential evidence }\end{array}$ \\
\hline
\end{tabular}

\section{Level of Evidence}

Level I

Level II

Level III

Level IV

Level V

Level VI

Level VII
Description

Evidence from a systematic review or meta-analysis of all relevant RCTs (randomized controlled trial) or evidence-based clinical practice guidelines based on systematic reviews of RCTs or three or more RCTs of good quality that have similar results.

Evidence obtained from at least one well-designed RCT (e.g. large multi-site RCT).

Evidence obtained from well-designed controlled trials without randomization (i.e. quasiexperimental).

Evidence from well-designed case-control or cohort studies.

Evidence from systematic reviews of descriptive and qualitative studies (meta-synthesis).

Evidence from a single descriptive or qualitative study.

Evidence from the opinion of authorities and/or reports of expert committees. 
Appendix F

SWOT Analysis Chart

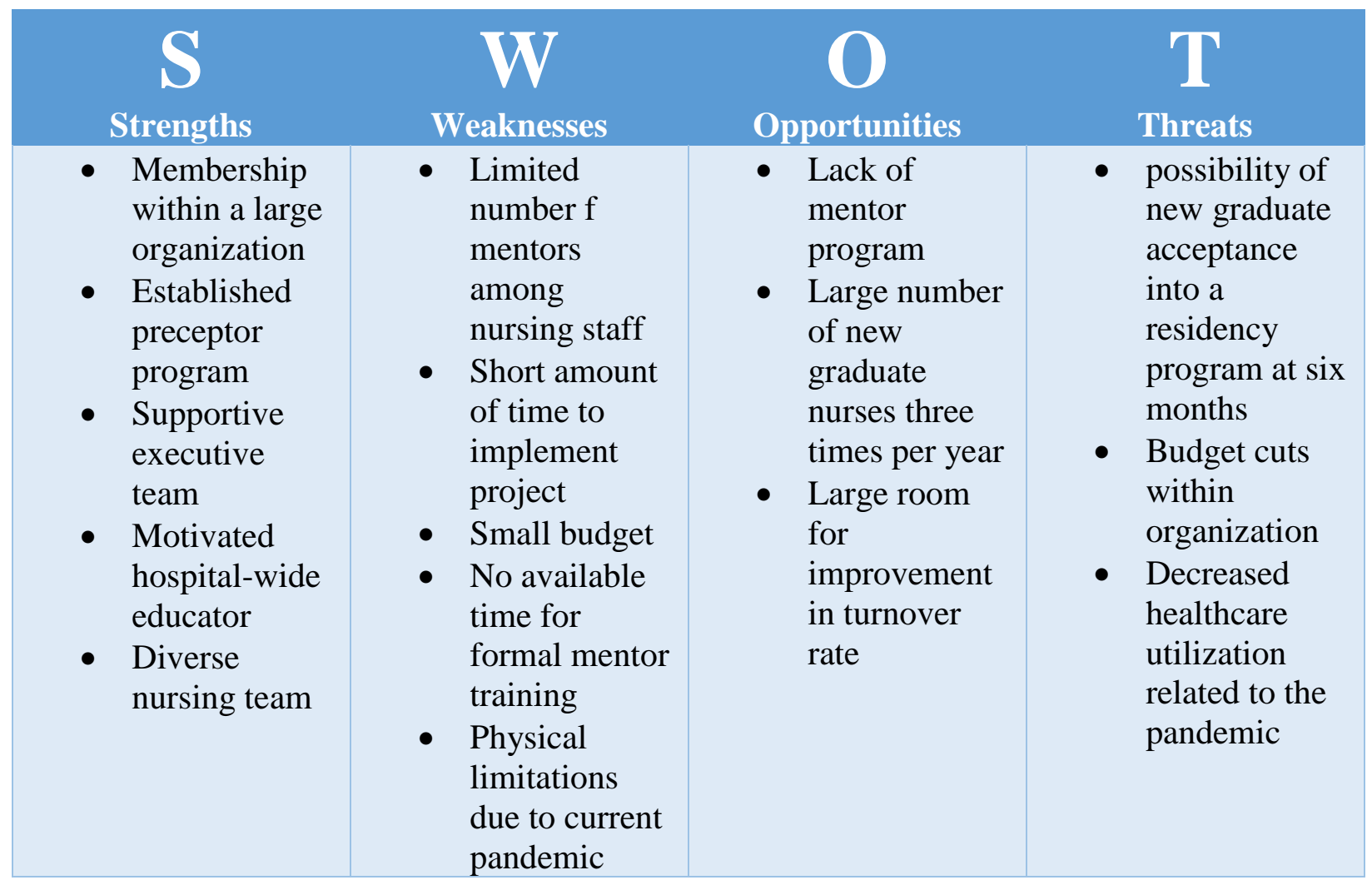




\section{Appendix G}

\section{Recruiting Flyer}

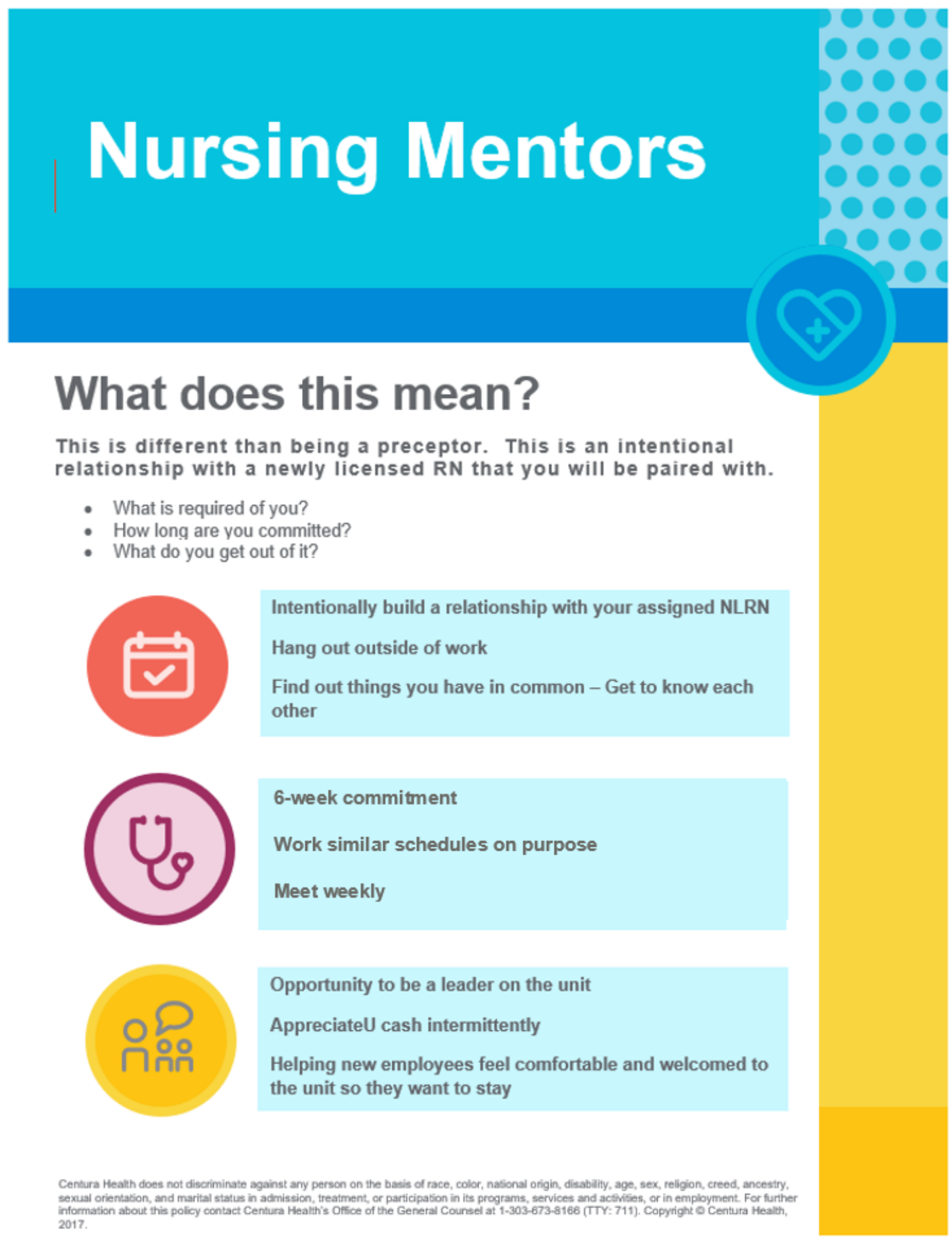


Appendix H Mentor Guide
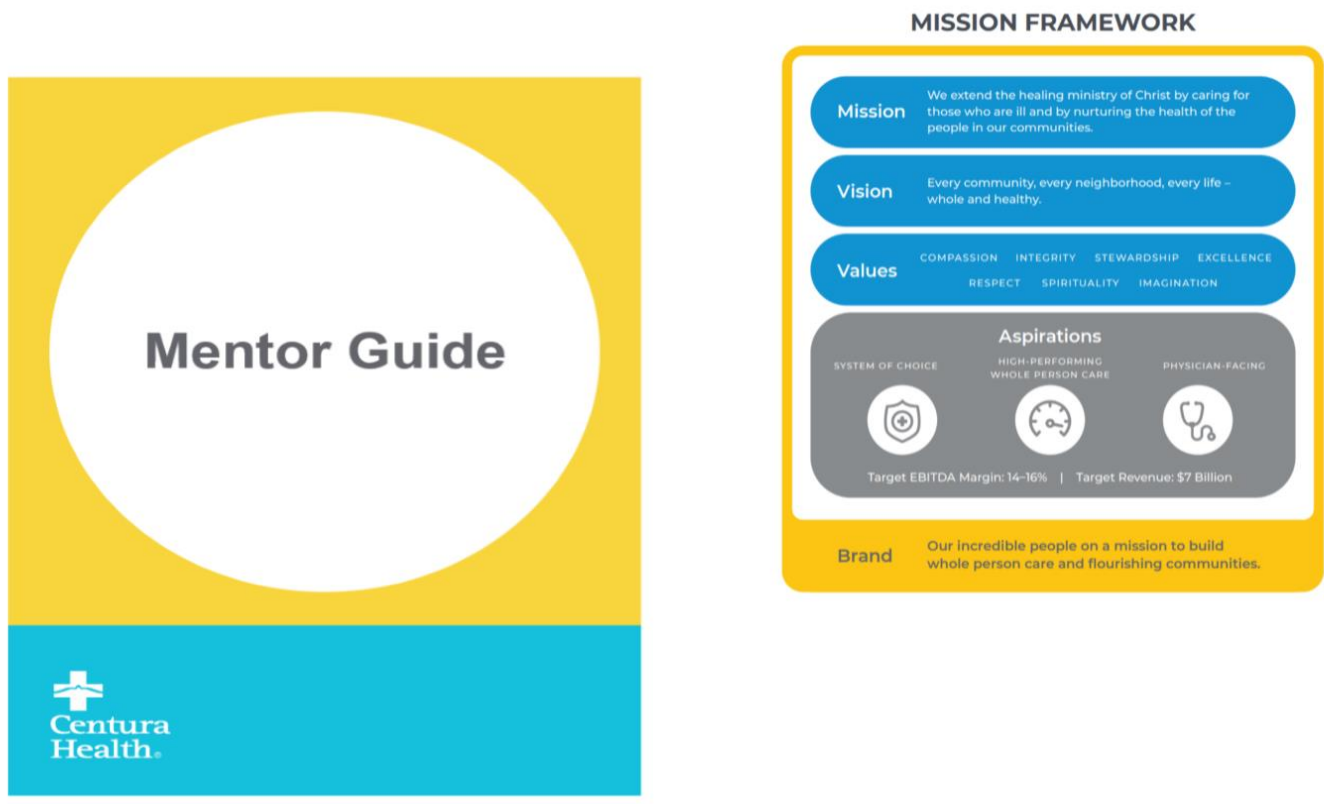

\section{Mentor Guide}

Becoming the mentor you wish you

always had

\section{Table of Contents}

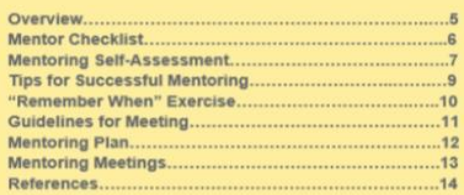

预 Centura Health. OVERVIEW

This mentoring program is designed to lead a (n) (mentor) and a newly licensed nurse (mentee).
This relationship is meant to serve as a vessel for the mutual transference of ideas, insights knowledge, caring and confidence. The program is
founded within the principals of adult learning. Through this program it is expected that the $\checkmark$ following objectives will be met $\checkmark$ relationships

$\checkmark$ Promoth collaboration and idea sharing This guide contains guidelines, exercises and tools establishing and maintaining an effective relationship with the mentee(s). This program was developed with hope that
burnout among new graduate nurses can be reduced and eliminated. The turnover rate among extremely high. This is due to a stressful work environment, poor tran
to the licensed nurse, to the licensed nurse, and the realization of the
responsibility that comes with nursing

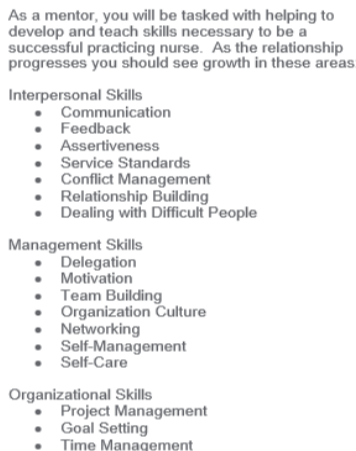


Centura Health.

\section{MENTOR'S CHECKLIST}

Directions: Read through the checklist, add additional items if appropriate, and check each item as Review the Mentor Guide you complete it.

Complete the Mentoring Self-Assessment

Complete the "Remember When" exercise

Meet with your mentee for the first time and obtain more information about them (resume, job history, family info, hobbies, etc.

Working with your mentee, fill out the Mentoring Program Plan. Remember that your NLRN will likely learm the best when they can apply their learning in real situations. Schedule future meetings with your mentee and encourage them to come prepared with items

At 6-weeks encourage your mentee to fill out the job satisfaction survey they will receive in their email

9. $\quad 2^{\text {nd }}$ Meeting

$10 . \quad 3$ rd Meeting

11. $4^{\text {th }}$ Meeting

$12 . \quad 5^{\text {th }}$ Meeting

13. Towards the end of the 6-week mentor relationship converse with your mentee about their new pregintent to stay on the job, goals for the next year, and their overall satisfaction with the

14. program.

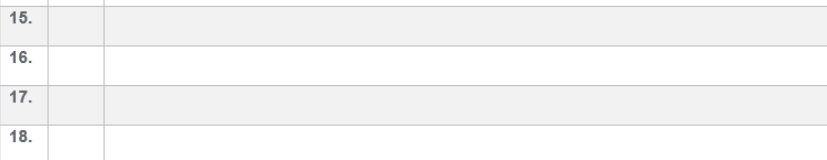

Centura Health. MENTORING SELF-ASSESSMENT

Directions: Assess your skills to determine your strengths and areas where you can improve your mentoring.
Read each behavior and, using a scale of $1-5$ ( 1 being no experience and 5 being an expert) rate your
experience level. After completing the assessment, review areas where you scored low, and focus on

1. I encourage mentees to express their honest feelings about their experiences. I

I initiate periodic progress reports to determine mentees' perceptions of their learning

3. I refer mentees to other individuals who may offer information and guidance in areas 4. I use eye contact when meeting with mentees.

5. I share my life experiences to help mentees learn from practical experience.

C. I encourage mentees to refer to the organization's mission and values when communicating and making decisions.

7. I encourage mentees to gather all the facts and define the problem before attempting

8. I ask probing questions and encourage mentees to reach their own conclusions and solve problems while providing helpful support. I try not to solve problems for them Hink mentees with leaning resources (human and malowa) to expand the

I encourage mentees to challenge the way things have always been done and "color outside the lines."

11. I point out inconsistencies in mentees' rationale for their actions and assist them in clearly thinking about their behaviors

12. I encourage mentees who are upset or discouraged about a mistake, fallure, or negative experience to identify what went wrong, determine reasons why and what could be done differently next time, and to learn from the experience.

13. I provide negative feedback privately and at times when I think mentees are ready or able to constructively receive this intormation.

I provide negative leedback to mentees by

a. making a positive commen

behavior/action

c. discussing ways to correct the situation and/or ways to improve in the future

5. I d. ending on a positive note of affirmation of the mentees' skills and abilities.

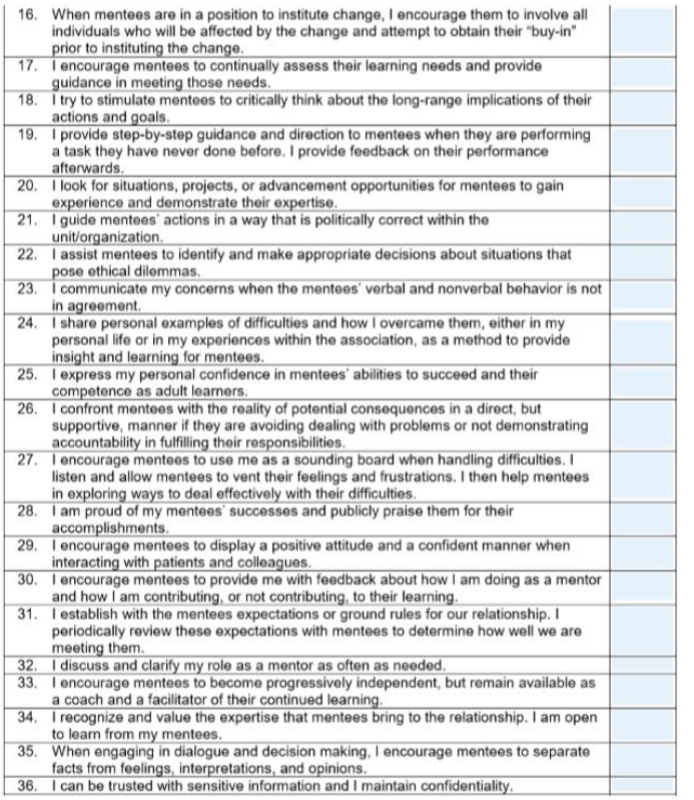

Centura Health.

TIPS FOR SUCCESS

- Be comfortable with the uncertainty of this type of a new relationship.

> Present the mentoring relationship as growth and development
Use adult learning principles.

Dxhibit exemplary/role model behavior.

> Be interested. Don't appear rushed.

$>$ Be clear about the necessity of meeting on a regular basis, even if any issues, problems, or dere to have needs. Expect your mentee to actively participate. Make appointments in advance and
keep them.

- Meet in an environment where there will be few, if any, interruptions.

> Introduce your mentee to coworkers. physicians, and other significant ndividuals.

> Offer guidance in the customs/culture unit/organization.

- Remember, it is the consistent interest. friendliness, and quality time that
builds a relationship of trust, wherein positive development occurs
Publicly praise your mentee's
accomplishments and abilities.

Recognize and encourage potential.

Drovide support in times of personal crises or problems.

> Monitor your mentee's progress

> Assist in making decisions through listening, support, and feedback.

- As a novice, provide specific direction to the mentee as independence when ready, while continuing to provide the proper

- Share appropriate life experiences to personalize and enrich the mentoring experience. Describing istakes made in a humorous (You wouldn't believe what ) did/said...").

> Encourage the mentee to tak risks and learn from mistakes.

> Agree to a no-fault termination of the relationship if it isn't working of 


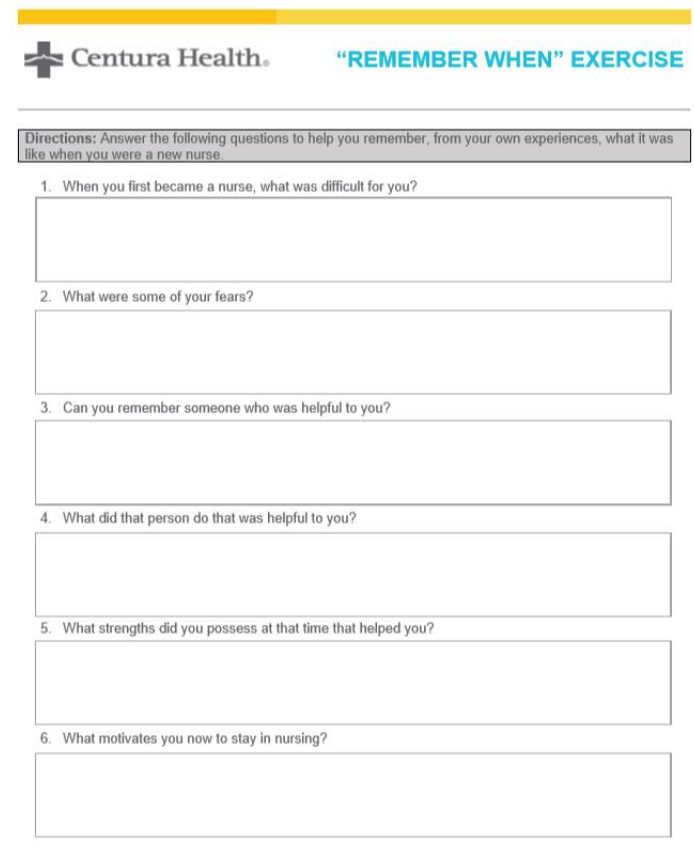

\section{Thentura Health. GUIDELINES FOR MEETING}

The purpose of the meetings with your mentee is to provide an environment of open communication Where you can discuss any and all aspects of your mentee's transition to a new position. Encourage The following guidelines will assist you in making your mentoring experience beneficial to you and
Tour

Meeting Topics The following are topics you and your mentee may discuss during your meetings. Your mentee's
immediate needs for the next few weeks/months The current demands of your mentee's work Feedback received from onters Somenting that went wiong recently something that went very well Issues Wishes

Tips for the First Meeting

You will be establishing the tone of the relationship in this first meeting. Remember that the mentee will be uncertain and may feel intimidated prior to meeting you

Be friendly, welcoming, reassuring, and encouraging. Ask about the mentee's experiences of the first week/month. Share something from your first week/month/day as a new nurse. Clarify your role Deut the mentoring program Remind your mentee or herhis gesponsbily n keepng appointments Discuss locations and times to meet that appeal to both of you (i.e., walk outside, lunch, etc.... start with what's comfortable). Arrive on time. Discuss the confidential basis of the mentoring relationship.

Subsequent Meetings

Begin by spending time developing the relationship aspects further (1.e., how has it been going: mentee's sell-assessment and other feecthack and guidance. Explore some of the following points it your mentee is having difficulty in formulating the meeting agendas: What kind of experiences have you had in a nursing postion have you had a mentor betire? Have you had any ideal role models? How did your mentorssrole models help you? What specific behaviors of your role models did you been able to do? What gets in your way? What would help you implement your wishes? Share some challenges you've had and describe how you handled them

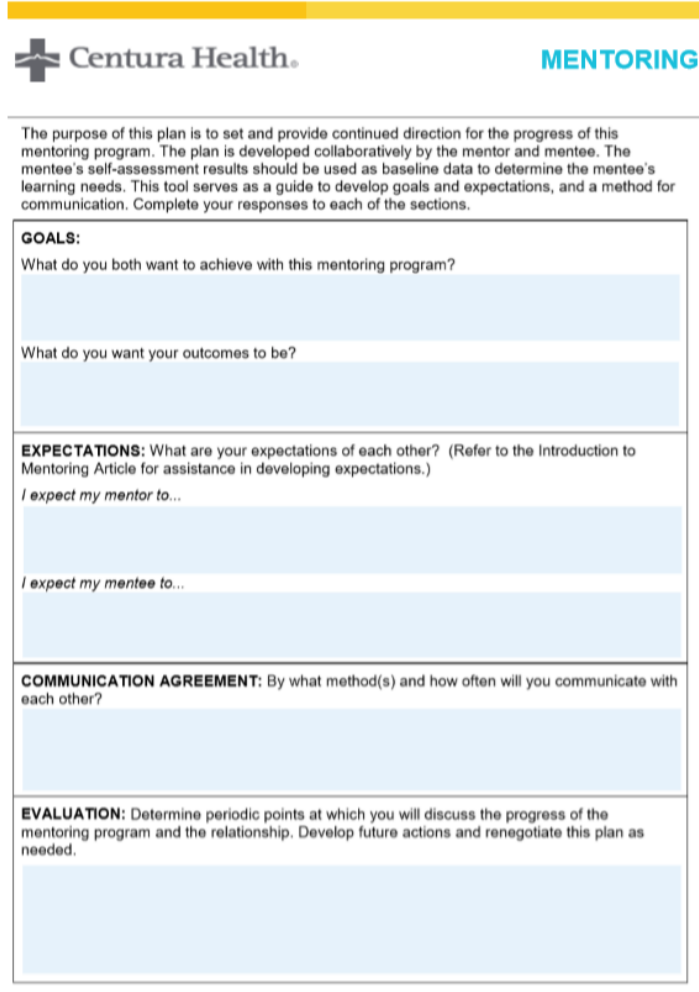

Centura Health.

MENTORING MEETINGS

The purpose of this plan is to set and provide continued direction for the progress of this entee's self-assessment results should be used as baseline data to determine the mentee GOALS:

What do you both want to achieve with this mentoring program?

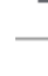

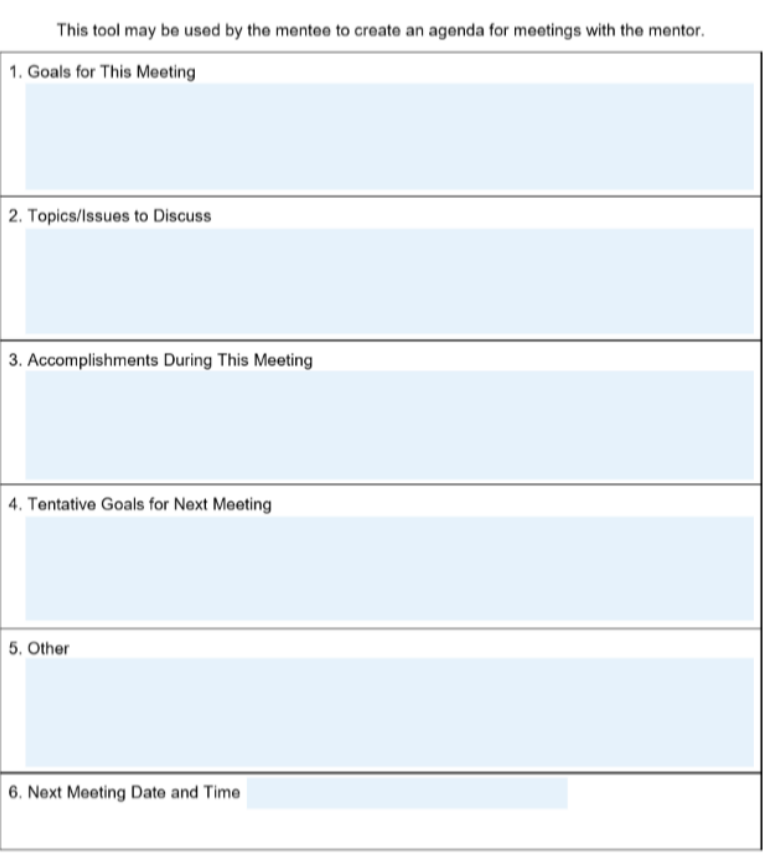


苗Centura Health. REFERENCES

Academy of Medical-Surgical Nurses (2012). AMSN mentoring program. Mentor guide [pdf]

Phillips-Jones, L. (2003). The mentor's guide [pdf]. Retrieved from https://mentoringgroup.com/books/the-

mentors-guide.pdf 
Appendix I

Project Schedule

\begin{tabular}{|c|c|c|c|c|c|c|c|c|c|c|c|c|c|c|c|c|c|c|c|c|c|c|c|c|}
\hline & \multicolumn{8}{|c|}{ NUR7801 } & \multicolumn{8}{|c|}{ NUR7802 } & \multicolumn{8}{|c|}{ NUR7803 } \\
\hline 空 & $\frac{\bar{y}}{\frac{\pi}{0}}$ & $\begin{array}{l}m \\
\frac{n}{0} \\
\frac{1}{3} \\
3\end{array}$ & $\begin{array}{l}n \\
\frac{1}{0} \\
3 \\
3\end{array}$ & $\frac{\bar{y}}{3}$ & $\begin{array}{l}\frac{a}{10} \\
\frac{0}{3}\end{array}$ & $\begin{array}{l}= \\
\frac{y}{8} \\
3\end{array}$ & $\begin{array}{l}\frac{m}{4} \\
\frac{\pi}{d} \\
\frac{D}{3}\end{array}$ & $\begin{array}{l}\frac{n}{2} \\
\frac{\pi}{d} \\
\frac{d}{3}\end{array}$ & $\frac{7}{3}$ & $\begin{array}{l}m \\
\frac{1}{2} \\
\frac{1}{3}\end{array}$ & $\begin{array}{l}n \\
\frac{y}{8} \\
\frac{d}{3}\end{array}$ & $\frac{\pi}{3}$ & $\begin{array}{l}a \\
\frac{y}{0} \\
z \\
z\end{array}$ & $\begin{array}{l}= \\
\frac{y}{8} \\
\frac{d}{3}\end{array}$ & $\begin{array}{l}\frac{m}{2} \\
\frac{y}{0} \\
\frac{d}{3}\end{array}$ & $\begin{array}{l}\frac{n}{3} \\
\frac{\pi}{0} \\
3\end{array}$ & $\begin{array}{l}\frac{7}{2} \\
\frac{0}{2} \\
3\end{array}$ & $\begin{array}{l}m \\
\frac{n}{2} \\
\frac{d}{3}\end{array}$ & $\begin{array}{l}n \\
\frac{2}{0} \\
\frac{0}{3}\end{array}$ & $\frac{\pi}{3}$ & $\begin{array}{l}\frac{9}{0} \\
\frac{10}{3} \\
3\end{array}$ & $\begin{array}{l}= \\
\frac{y}{8} \\
3\end{array}$ & $\begin{array}{l}\frac{n}{4} \\
\frac{1}{2} \\
\frac{D}{3}\end{array}$ & $\frac{n}{\frac{n}{2}}$ \\
\hline $\begin{array}{l}\text { Meet with director of } \\
\text { quality }\end{array}$ & & & & & & & & & & & & & & & & & & & & & & & & \\
\hline $\begin{array}{l}\text { Develop Project } \\
\text { Proposal }\end{array}$ & & & & & & & & & & & & & & & & & & & & & & & & \\
\hline $\begin{array}{l}\text { Develop mentor } \\
\text { training }\end{array}$ & & & & & & & & & & & & & & & & & & & & & & & & \\
\hline Meet with educators & & & & & & & & & & & & & & & & & & & & & & & & \\
\hline Seek admin approval & & & & & & & & & & & & & & & & & & & & & & & & \\
\hline Seek EBPC approval & & & & & & & & & & & & & & & & & & & & & & & & \\
\hline $\begin{array}{l}\text { In-person training wi } \\
\text { mentors }\end{array}$ & & & & & & & & & & & & & & & & & & & & & & & & \\
\hline $\begin{array}{l}\text { Present to Admin } \\
\text { Council and unit } \\
\text { leadership }\end{array}$ & & & & & & & & & & & & & & & & & & & & & & & & \\
\hline $\begin{array}{l}\text { Program Maintenanc } \\
\text { (check-ins with } \\
\text { mentors and protégés }\end{array}$ & & & & & & & & & & & & & & & & & & & & & & & & \\
\hline $\begin{array}{l}\text { Check-In with } \\
\text { Preceptor }\end{array}$ & & & & & & & & & & & & & & & & & & & & & & & & \\
\hline Final Survey & & & & & & & & & & & & & & & & & & & & & & & & \\
\hline Collect data & & & & & & & & & & & & & & & & & & & & & & & & \\
\hline Compare outcomes & & & & & & & & & & & & & & & & & & & & & & & & \\
\hline $\begin{array}{l}\text { Evaluation and } \\
\text { Dissemination }\end{array}$ & & & & & & & & & & & & & & & & & & & & & & & & \\
\hline
\end{tabular}


Appendix J

\section{GANNT Chart}

Reducing Burnout Among New Graduate Nurses

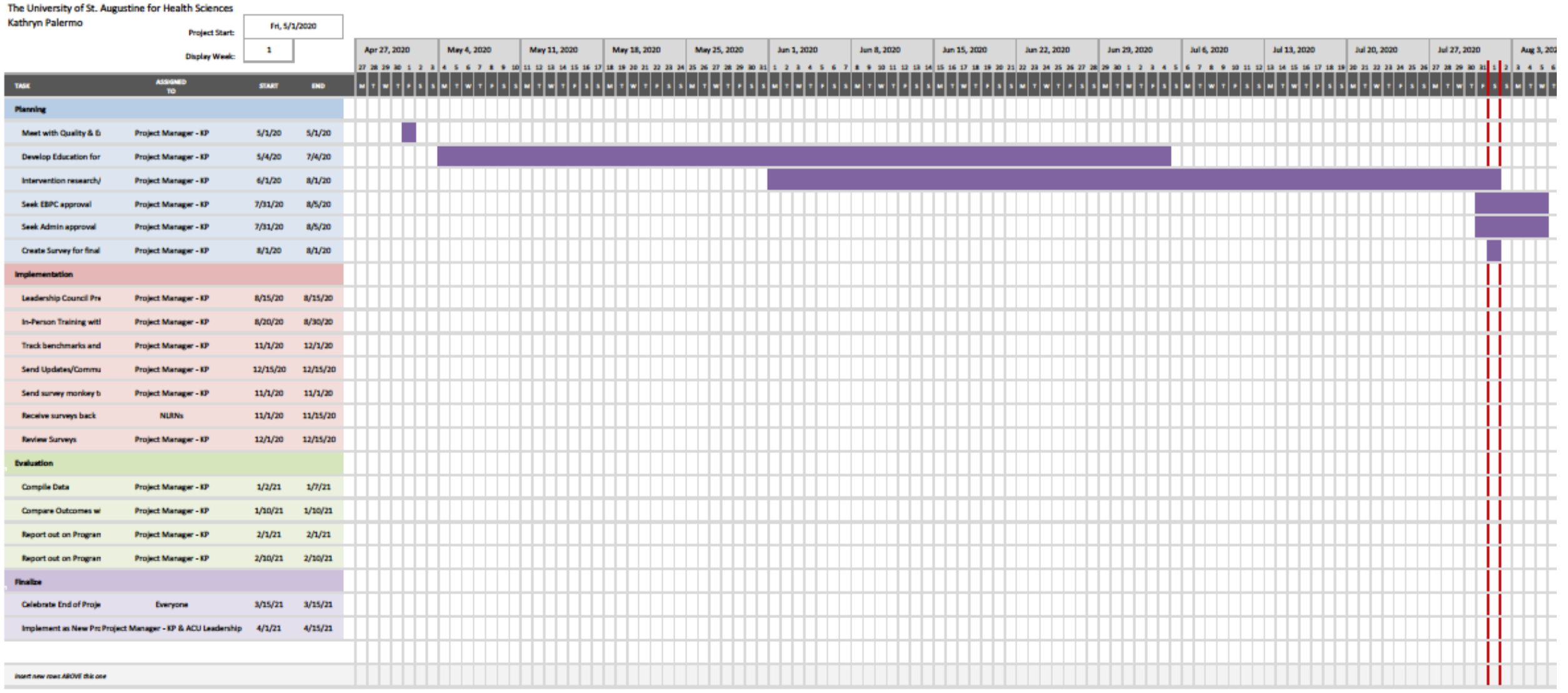




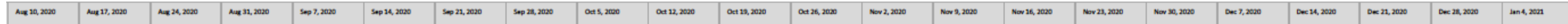
юr.
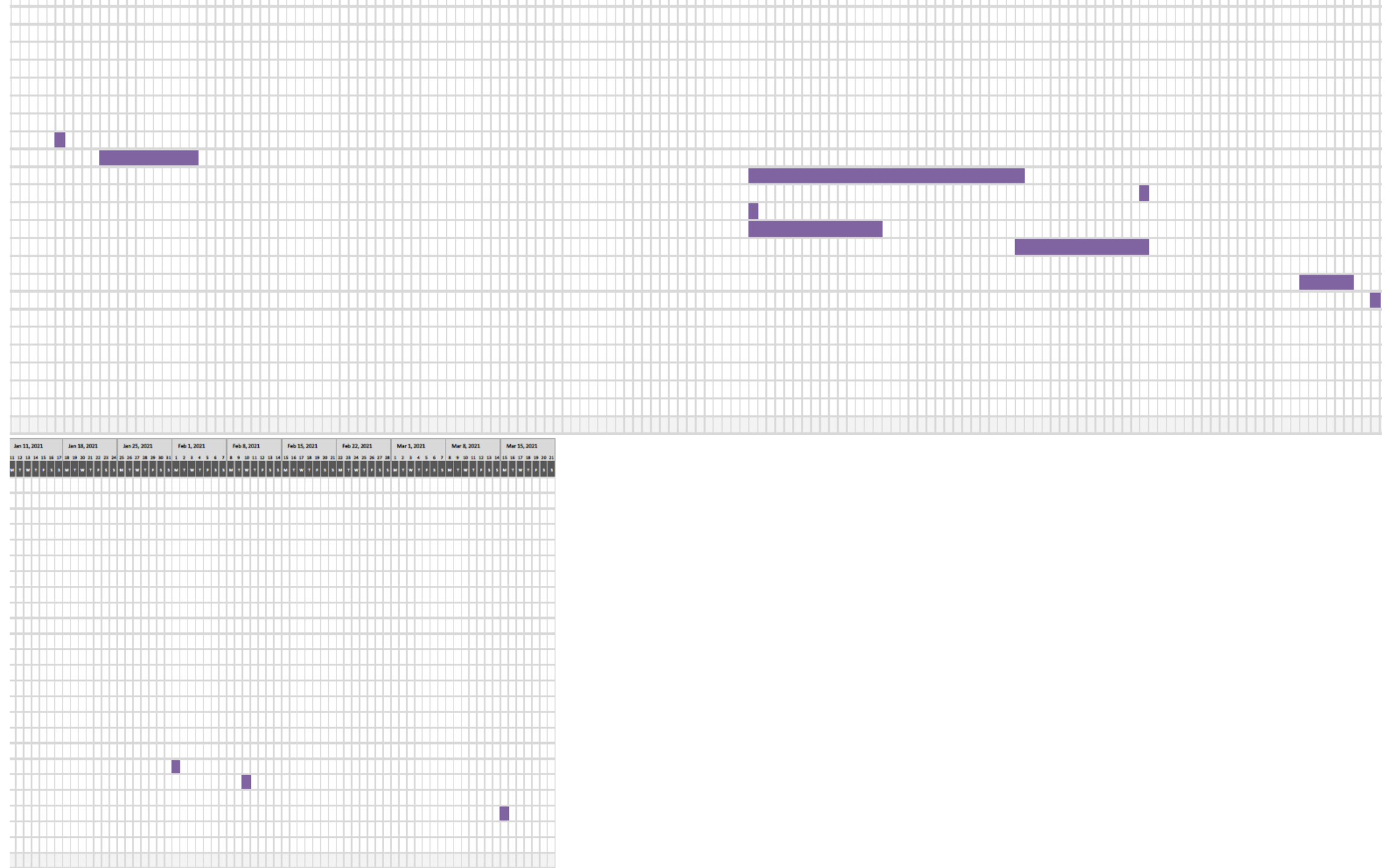
Appendix K

Survey Questions

\section{Final Survey Questions - Mentee}

1. Do you intend to continue working on Acute Care beyond 12 months from your hire date?

2. Do you intend to continue working on Acute Care Yes/No beyond 18 months from your hire date?

3. Has your mentor had an impact on your intention to stay Yes/No or leave?

4. What factors have influenced your decision to stay or Comment leave?

5. Would you recommend the mentor program to continue

Comment for future NLRNs?

\section{Final Survey Questions - Mentor}

1. Do you intend to continue working on Acute Care for the next 12 months?

2. On a scale of 1-10 how would you rate your job

Yes/No satisfaction?

3. Has your participation as a mentor influenced your job satisfaction positively?

4. What factors have influenced your decision to stay or leave?

5. Would you recommend the mentor program to continue $1-10$

Yes/No

Comment for future NLRNs?

Comment 


\section{Appendix L}

\section{Mentor Survey}

Frequency Table for Nominal and Ordinal Variables

\begin{tabular}{|c|c|c|}
\hline Variable & $n$ & $\%$ \\
\hline \multicolumn{3}{|c|}{ Intention_to_work_past_12_months } \\
\hline yes & 3 & 60.00 \\
\hline no & 2 & 40.00 \\
\hline Missing & 0 & 0.00 \\
\hline \multicolumn{3}{|l|}{ Gender } \\
\hline Female & 4 & 80.00 \\
\hline Male & 1 & 20.00 \\
\hline Missing & 0 & 0.00 \\
\hline \multicolumn{3}{|c|}{ Has_the_Mentorship_impacted_you_positively } \\
\hline Yes & 5 & 100.00 \\
\hline Missing & 0 & 0.00 \\
\hline \multicolumn{3}{|c|}{ Recommend_the_program } \\
\hline Yes & 5 & 100.00 \\
\hline Missing & 0 & 0.00 \\
\hline
\end{tabular}

Note. Due to rounding errors, percentages may not equal $100 \%$.

Mentor job satisfaction

Summary Statistics Table for Interval and Ratio Variables

\begin{tabular}{lrrrrrrrr}
\hline Variable & $M$ & $S D$ & $n$ & $S E_{M}$ & Min & Max & Skewness & Kurtosis \\
\hline Job_Satisfaction & 6.80 & 1.30 & 5 & 0.58 & 5.00 & 8.00 & -0.36 & -1.37 \\
\hline
\end{tabular}

Mentee Survey

Frequency Table for Ordinal Variables

\begin{tabular}{|c|c|c|}
\hline Variable & $n$ & $\%$ \\
\hline \multicolumn{3}{|c|}{ Intention_to_work_past_18_months } \\
\hline No & 2 & 40.00 \\
\hline Yes & 3 & 60.00 \\
\hline Missing & 0 & 0.00 \\
\hline
\end{tabular}


Gender

Female

3

Male

240.00

Missing

$0 \quad 0.00$

Has_the_Mentor_impacted_you_decision_to_stay_or_leave

No

Yes

$1 \quad 20.00$

Missing

$4 \quad 80.00$

Recommend_the_program

$\begin{array}{ll}0 & 0.00\end{array}$

Yes

$5 \quad 100.00$

Missing

$0 \quad 0.00$

Intention_to_work_past_12_months

No

120.00

Yes

Missing

0.00

Note. Due to rounding errors, percentages may not equal $100 \%$. 